\title{
An overview of the appendicular skeletal anatomy of South American titanosaurian sauropods, with definition of a newly recognized clade
}

\author{
BERNARDO J. GONZÁLEZ RIGA ${ }^{1}$, MATTHEW C. LAMANNA ${ }^{2}$, ALEJANDRO OTERO ${ }^{3}$, \\ LEONARDO D. ORTIZ DAVID ${ }^{1}$, ALEXANDER W.A. KELLNER ${ }^{4}$ and LUCIO M. IBIRICU ${ }^{5}$
}

${ }^{1}$ CONICET/Laboratorio y Museo de Dinosaurios, Facultad de Ciencias Exactas y Naturales, Universidad Nacional de Cuyo, Padre Contreras 1300, Parque Gral. San Martin, Mendoza Capital 5500, Mendoza, Argentina

${ }^{2}$ Section of Vertebrate Paleontology, Carnegie Museum of Natural History, 4400

Forbes Avenue, Pittsburgh, Pennsylvania 15213, U.S.A.

${ }^{3}$ CONICET, División Paleontología de Vertebrados, Museo de La Plata, Paseo del Bosque, s/n, La Plata, B1900FWA, Argentina

${ }^{4}$ Laboratório de Systemática e Tafonomia de Vertebrados Fósseis, Departamento de Geologia e Paleontologia, Museu Nacional, Universidade Federal do Rio de Janeiro, Quinta da Boa Vista, São Cristóvão, 20940-040 Rio de Janeiro, RJ, Brazil

${ }^{5}$ Instituto Patagónico de Geología y Paleontología (IPGP-CONICET), Boulevard

Almirante Brown, 2915, Puerto Madryn, 9120, Chubut, Argentina

Manuscript received on April 18, 2018; accepted for publication on January 28, 2019

\begin{abstract}
How to cite: GONZÁLEZ RIGA BJ, LAMANNA MC, OTERO A, ORTIZ DAVID LD, KELLNER AWA AND IBIRICU LM. 2019. An overview of the appendicular skeletal anatomy of South American titanosaurian sauropods, with definition of a newly recognized clade. An Acad Bras Cienc 91:e20180374. DOI 10.1590/0001-3765201920180374.
\end{abstract}

\begin{abstract}
In the last two decades, the number of phylogenetically informative anatomical characters recognized in the appendicular skeleton of titanosaurian sauropod dinosaurs has increased dramatically with the discovery of new and comparatively complete specimens. Here we provide an overview of the appendicular skeletal morphology of South American titanosaurs and discuss its significance for phylogenetic reconstruction. The appendicular skeletal diversity of South American titanosaurs is substantially greater than was initially appreciated. Moreover, some regions of the appendicular skeleton, such as the pes, exhibit remarkable variability in form. Multiple synapomorphies of Titanosauria and the less inclusive clades Lithostrotia and Saltasauridae consist of characters of the girdles and limbs. Although the phylogenetic definitions of titanosaurian clades such as Saltasaurinae and Lognkosauria are stable, the taxonomic content of these clades has varied in recent analyses depending on the phylogenetic topology recovered. Within Titanosauria, the results of four recent, largely independent analyses support the existence of a derived titanosaurian lineage distinct from the 'Saltasaurinae line,' which is herein termed Colossosauria. At present, this clade is mainly comprised by taxa within Lognkosauria and Rinconsauria, and is useful in discussions of titanosaurian lower-level relationships.
\end{abstract}

Key words: Titanosauria, South America, appendicular skeleton, osteology, phylogeny, Colossosauria.

Correspondence to: Bernardo Javier González Riga

E-mail: bgonriga@yahoo.com.ar

ORCid: https://orcid.org/0000-0002-6051-472X

* Contribution to the centenary of the Brazilian Academy of

Sciences. 


\section{INTRODUCTION}

Titanosaurian sauropods were the most diverse and abundant large-bodied terrestrial herbivores in the Southern Hemisphere landmasses during the Late Cretaceous (Bonaparte and Powell 1980, Calvo and Bonaparte 1991, Bonaparte and Coria 1993, Bonaparte 1996, Jain and Bandyopadhyay 1997, Salgado et al. 1997, Curry Rogers and Forster 2001, Smith et al. 2001, Powell 2003, Wilson and Upchurch 2003, Upchurch et al. 2004, Curry Rogers 2005, Wilson 2006, Hocknull et al. 2009, González Riga 2011, Wilson et al. 2011, Curry Rogers and Wilson 2014, Gorscak et al. 2014, 2017, Lacovara et al. 2014, Otero and Salgado 2015, Poropat et al. 2015, 2016, González Riga et al. 2016, 2018, Gorscak and O'Connor 2016, Carballido et al. 2017, Sallam et al. 2018). Fossils of these dinosaurs have been discovered on all continents, and titanosaurian taxa currently comprise approximately one third of known sauropod diversity. The number of named titanosaurs has increased dramatically in recent years (e.g., Curry Rogers 2005, González Riga 2011, Cerda et al. 2012, D'Emic 2012, Mannion et al. 2013, Lacovara et al. 2014, Wilson et al. 2016), with roughly 50 valid species presently recognized from South America alone (M.C.L. pers. obs.). Furthermore, some taxa are regarded as the most massive terrestrial animals known to science (Bonaparte and Coria 1993, Smith et al. 2001, Novas et al. 2005, Sander et al. 2011, Calvo 2014, Lacovara et al. 2014, González Riga et al. 2016, Carballido et al. 2017). Titanosaurs were particularly diverse during the latest Cretaceous, and encompass a taxonomic richness that rivals that of the hadrosaurid and ceratopsid ornithischians that dominated many Northern Hemisphere paleoecosystems at the same time (Mannion et al. 2011, González Riga et al. 2016).

Anatomical and phylogenetic analyses of titanosaurs are crucial for deciphering the evolutionary history and paleobiology of these singular animals, but such studies have been hampered by missing data, as the osteology of many titanosaurian species is not well understood. Fortunately, this situation is beginning to change with recent discoveries and descriptions of wellpreserved, comparatively complete specimens of taxa such as Tapuiasaurus from the Early Cretaceous of Brazil (Zaher et al. 2011, Wilson et al. 2016), Bonitasaura (Apesteguía 2004, Gallina 2011, Gallina and Apesteguía 2011, 2015), Dreadnoughtus (Lacovara et al. 2014, Ullmann and Lacovara 2016, Voegele et al. 2017), Epachthosaurus (Martínez et al. 2004), Futalognkosaurus (Calvo et al. 2007a, b), Mendozasaurus (González Riga 2003, 2005, González Riga et al. 2018), Overosaurus (Coria et al. 2013), and Patagotitan (Carballido et al. 2017) from the mid- and Late Cretaceous of Argentina; Rapetosaurus (Curry Rogers and Forster 2001, 2004, Curry Rogers 2009) from the latest Cretaceous of Madagascar; Mansourasaurus (Sallam et al. 2018), Rukwatitan (Gorscak et al. 2014), and Shingopana (Gorscak et al. 2017) from the Late Cretaceous of Africa; Diamantinasaurus (Hocknull et al. 2009, Poropat et al. 2015, 2016) and Savannasaurus (Poropat et al. 2016) from the Late Cretaceous of Australia, and Lohuecotitan (Díez Díaz et al. 2016) from the Late Cretaceous of Europe. Nevertheless, some areas of the titanosaurian skeleton remain poorly understood. For instance, the morphology of the appendicular skeleton has been extensively documented in only a few taxa, such as Bonitasaura (Apesteguía 2004, Gallina and Apesteguía 2015), Diamantinasaurus (Hocknull et al. 2009, Poropat et al. 2015), Dreadnoughtus (Lacovara et al. 2014, Ullmann and Lacovara 2016), Epachthosaurus (Martínez et al. 2004), Neuquensaurus (Otero 2010), Opisthocoelicaudia (Borsuk-Bialynicka 1977), Rapetosaurus (Curry Rogers 2009), and Saltasaurus (Powell 1992, 2003). More specifically, the distal forelimb is not well known in 
most titanosaurs, and in some taxa, the presence or absence of ossified carpals and manual phalanges is controversial (see, e.g., Apesteguía 2005, Mannion and Otero 2012, Poropat et al. 2015). Similarly, the pes of titanosaurs is poorly known; until recently, complete, articulated pedes were known only in Epachthosaurus and Opisthocoelicaudia. Fortunately, knowledge of titanosaurian pedal osteology has recently been enhanced by the discovery of the giant titanosaur Notocolossus from the Late Cretaceous of Mendoza Province, Argentina (González Riga et al. 2016) plus two other, as-yet unnamed species from Mendoza (the 'Agua del Padrillo taxon,' UNCUYO-LD 313, González Riga et al. 2015) and Neuquén (the 'La Invernada taxon,' MUCPv-1533, González Riga et al. 2008a) provinces, respectively (Figure 1). Furthermore, nearly complete pedes are known for a few other titanosaurs as well, such as Bonitasaura (Gallina and Apesteguía 2015), Mendozasaurus (González Riga et al. 2018), Rapetosaurus (Curry Rogers 2009), and possibly Alamosaurus (the latter based on NMMNH P-49967, a questionably referred specimen from the Upper Cretaceous of the southwestern U.S.A., D'Emic et al. 2011). The pes is very incompletely known in most other titanosaurs.

As noted above, phylogenetic analyses of titanosaurs are important as a basis for further evolutionary and paleobiogeographic interpretations pertaining to this widespread sauropod clade (e.g., Upchurch 1995, 1998, Salgado et al. 1997, Wilson and Sereno 1998, Wilson 2002, Upchurch et al. 2004, Curry Rogers 2005, D’Emic 2012, Mannion et al. 2013, González Riga et al. 2016, 2018, Gorscak and O'Connor 2016, Poropat et al. 2016, Sallam et al. 2018). Appendicular character states often comprise a significant component of the data employed in such analyses (e.g., D'Emic 2012, Mannion et al. 2013, González Riga et al. 2016, Gorscak and O'Connor 2016); moreover, some of these characters constitute synapomorphies of particular titanosaurian clades.

Many aspects of the girdle and limb morphology of titanosaurs (plus additional taxa within the more inclusive neosauropod clade Macronaria, Wilson and Sereno 1998) have been interpreted as being related to the acquisition of wide-gauge posture, where the manus and pedes are located at a considerable distance from the sagittal midline. This interpretation has been supported by many Late Cretaceous sauropod trackways attributed to derived titanosaurs (e.g., Farlow 1992, Lockley et al. 1994, Calvo 1999, Wilson and Carrano 1999, Wilson 2006, González Riga and Calvo 2009). However, several exceptions to this potential correlation between appendicular morphology and posture have also been recognized in the ichnological record (e.g., Lockley et al. 2002, Stevens et al. 2016), and as such, it is now customary for well-preserved trackways to be carefully analyzed, including studies of gait (e.g., Vila et al. 2008, González Riga and Tomaselli 2019). Additionally, computer-aided biomechanical studies are casting new light on the stance and locomotion of sauropods in general (Klinkhamer et al. 2018).

Another complex paleobiological aspect of Titanosauria is the gigantism attained by some lineages and its relationship to appendicular osteology. Wilson and Carrano (1999) and Carrano (2005) argued that many appendicular features seen in titanosaurs and other sauropods - such as graviportal, columnar limb posture, increased limb bone robusticity, shortened distal limb segments, and increased femoral midshaft eccentricityappear intimately related to the acquisition of large body size. As in other quadrupedal dinosaurs, the manus and pes of sauropods exhibit phalangeal reduction (Osborn 1904, Coombs 1975, Upchurch 1995, 1998, Wilson and Sereno 1998). Typically, such reduction occurred primarily in terms of length, with individual phalanges becoming compact and 

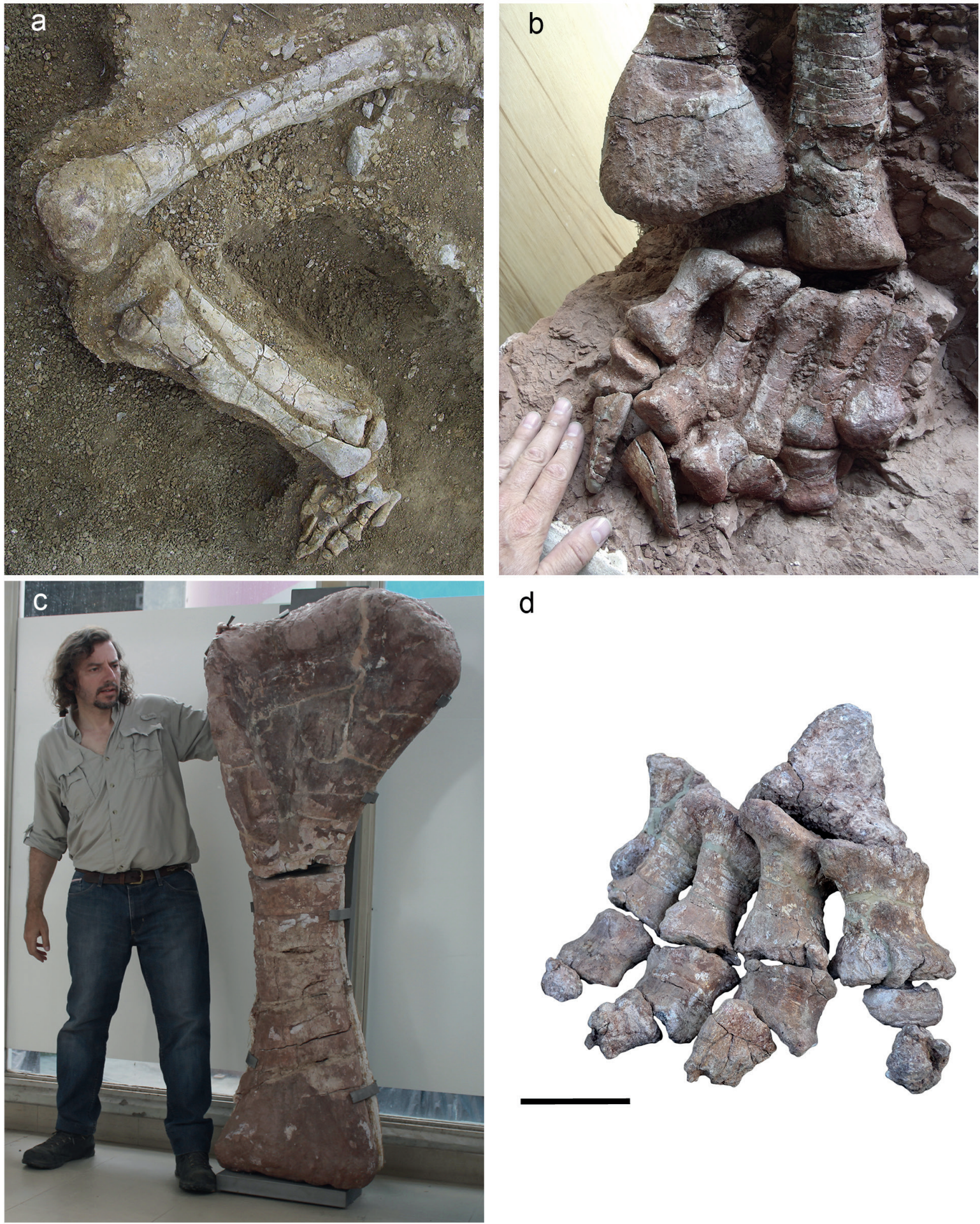

d

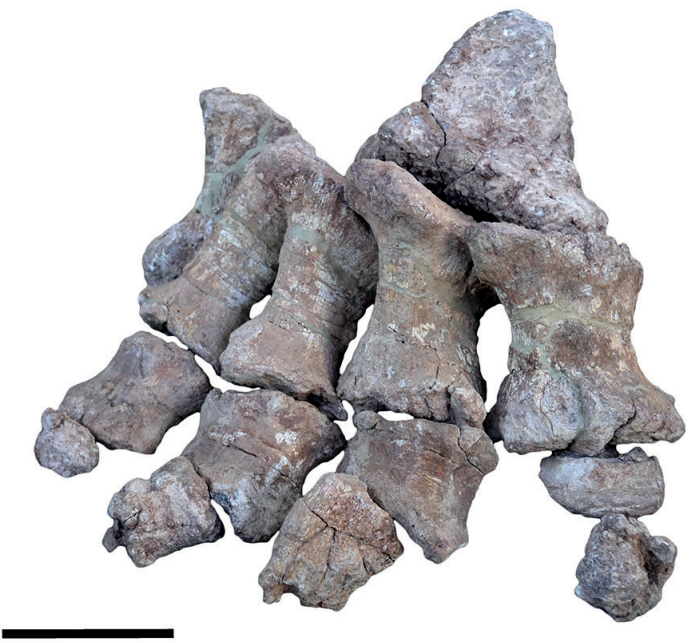

Figure 1 - Recent discoveries of appendicular skeletal elements of Late Cretaceous titanosaurian sauropods from the Neuquén Basin of southern Argentina. (a) complete and articulated left hind limb of the unnamed La Invernada taxon (MUCPv-1533), (b) complete and articulated distal left hind limb of the unnamed Agua del Padrillo taxon (UNCUYO-LD 313), (c) right humerus of Notocolossus gonzalezparejasi (UNCUYO-LD 301), (d) complete and articulated right pes of Notocolossus gonzalezparejasi (UNCUYO-LD 302). Scale bar equals $10 \mathrm{~cm}$ in (d). 
often disc-like. However, titanosaurs continued this trend, with many taxa reducing and in some cases apparently eliminating ossified manual phalanges. Furthermore, titanosaurs also exhibit the most reduced pedal phalangeal formulae seen within Sauropoda (Borsuk-Bialynicka 1977, Salgado et al. 1997, Wilson and Sereno 1998, Martínez et al. 2004, Apesteguía 2005, González Riga et al. 2008a, 2016).

In the present contribution, we provide an overview of titanosaurian appendicular skeletal anatomy, focusing on the many representatives of this clade that have been recovered from the Cretaceous of South America. We also discuss several of the principal appendicular skeletal characters that have been used in previous phylogenetic analyses of Titanosauria and its subclades, with the goal of identifying areas of agreement and conflict. Finally, we formally define a new clade of derived South American titanosaurs, recognized on the basis of results of recent cladistic analyses.

\section{INSTITUTIONAL ABBREVIATIONS}

AMNH, American Museum of Natural History, New York, U.S.A, CM, Carnegie Museum of Natural History, Pittsburgh, U.S.A.; CPP, Centro de Pesquisas Paleontológicas Llewellyn Price, Peirópolis, Brazil; FMNH, Field Museum of Natural History, Chicago, U.S.A.; IANIGLA, Instituto Argentino de Nivología, Glaciología y Ciencias Ambientales, Colección de Paleovertebrados, Mendoza, Argentina; MACN, Museo Argentino de Ciencias Naturales 'Bernardino Rivadavia,' Buenos Aires, Argentina; MAU (MRS), Museo 'Argentino Urquiza,' Rincón de Los Sauces, Argentina; MCS, Museo de Cinco Saltos, Cinco Saltos, Argentina; MLP, Museo de La Plata, La Plata, Argentina; MMCh, Museo Municipal 'Ernesto Bachmann,' Villa El Chocón, Argentina; MPEF, Museo Paleontológico Egidio Feruglio, Trelew, Argentina; MPM,
Museo Padre Molina, Río Gallegos, Argentina; MUCPv, Museo de Geología y Paleontología de la Universidad Nacional del Comahue, Neuquén, Argentina; NMMNH, New Mexico Museum of Natural History and Science, Albuquerque, U.S.A.; PVL, Fundación-Instituto Miguel Lillo, Tucumán, Argentina; SGO, Museo Nacional de Historia Natural, Santiago, Chile; UNCUYO-LD, Laboratorio y Museo de Dinosaurios, Universidad Nacional de Cuyo, Mendoza, Argentina; UNPSJBPV, Universidad Nacional de la Patagonia San Juan Bosco, Paleontología de Vertebrados, Comodoro Rivadavia, Argentina; USNM, National Museum of Natural History, Smithsonian Institution, Washington, D.C., U.S.A.; YPM, Yale Peabody Museum, New Haven, U.S.A.; ZPAL, Instytut Paleobiologii PAN, Warszawa, Poland.

\section{THE PECTORAL AND FORELIMB SKELETON OF SOUTH AMERICAN TITANOSAURS}

Although the fossil record of South American titanosaurs is rich in terms of numbers of specimens and species, taxa with completely known pectoral girdles and forelimbs are scarce (Table I). Exceptions include Epachthosaurus (Martínez et al. 2004) and the saltasaurines Neuquensaurus (Otero 2010) and Saltasaurus (Powell 1992, 2003), for which the pectoral girdle and forelimb are almost completely known, and to a lesser extent Argyrosaurus (Mannion and Otero 2012), Dreadnoughtus (Lacovara et al. 2014, Ullmann and Lacovara 2016), Mendozasaurus (González Riga 2003, 2005, González Riga et al. 2018), Muyelensaurus (Calvo et al. 2007c), Patagotitan (Carballido et al. 2017), Tapuiasaurus (Zaher et al. 2011), and Uberabatitan (Salgado and de Souza Carvalho 2008). The pectoral girdles and forelimbs of South American titanosaurs exhibit the basic anatomical plan of sauropods in general, but also possess unique features that differentiate them from those of non-titanosaurian taxa. 


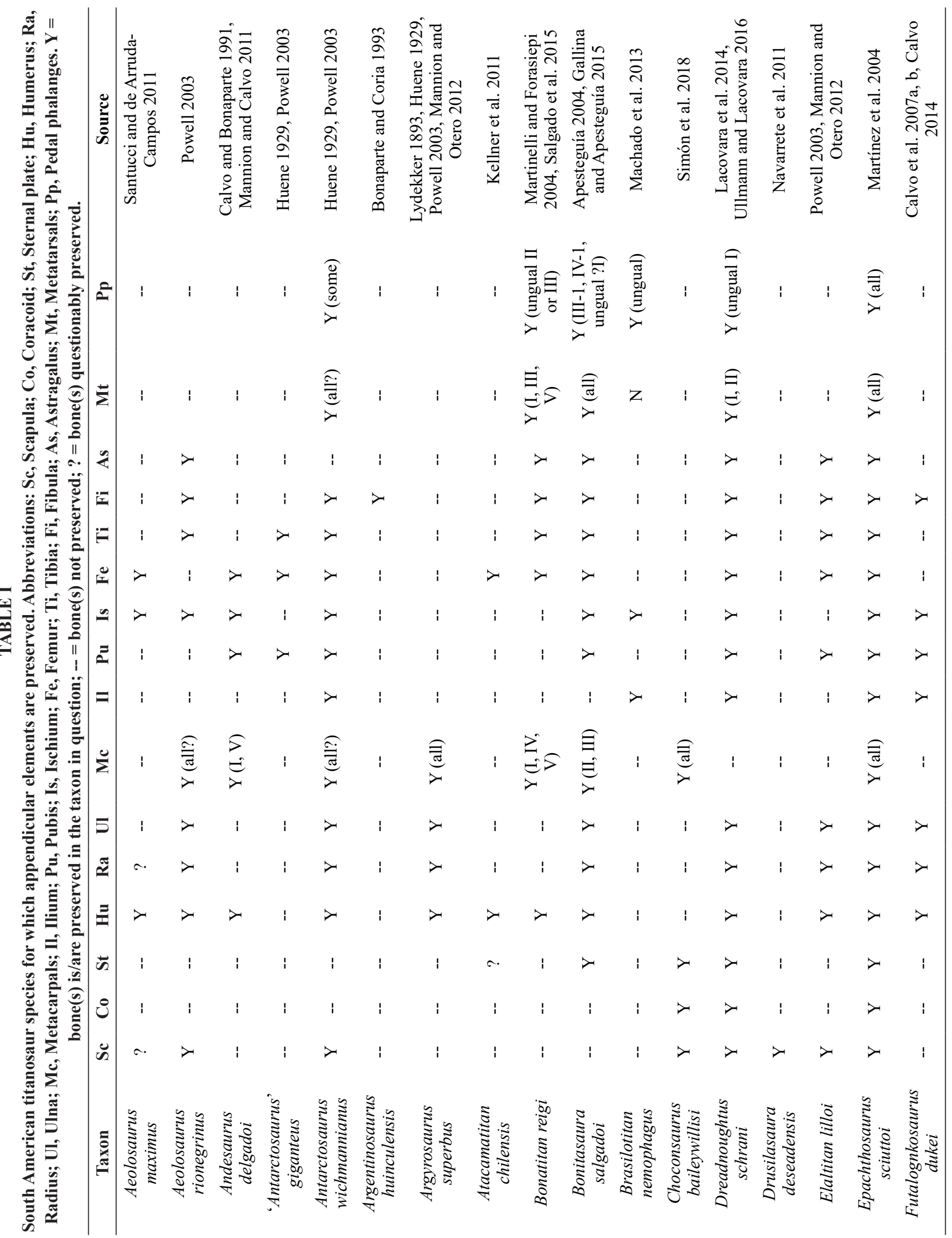




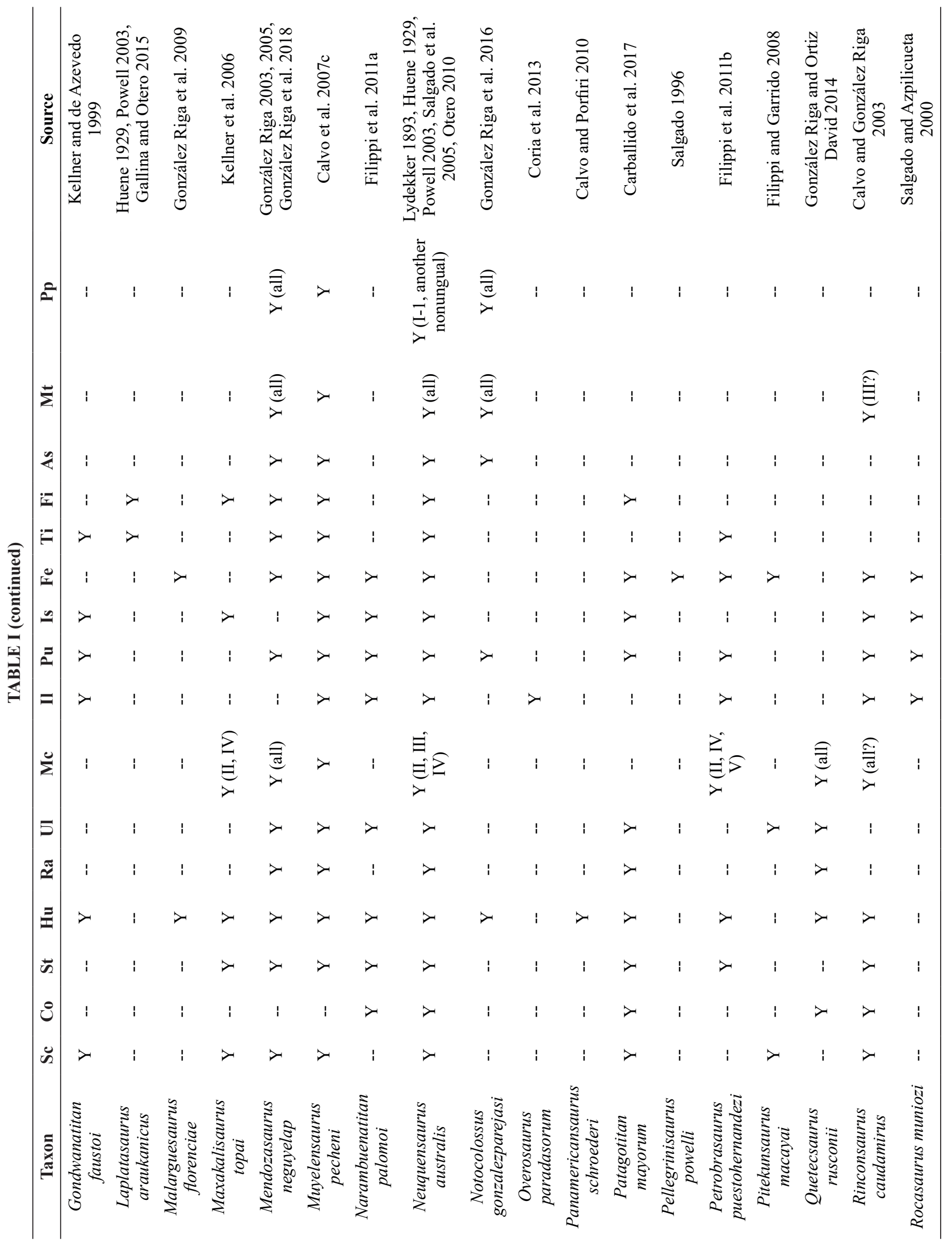




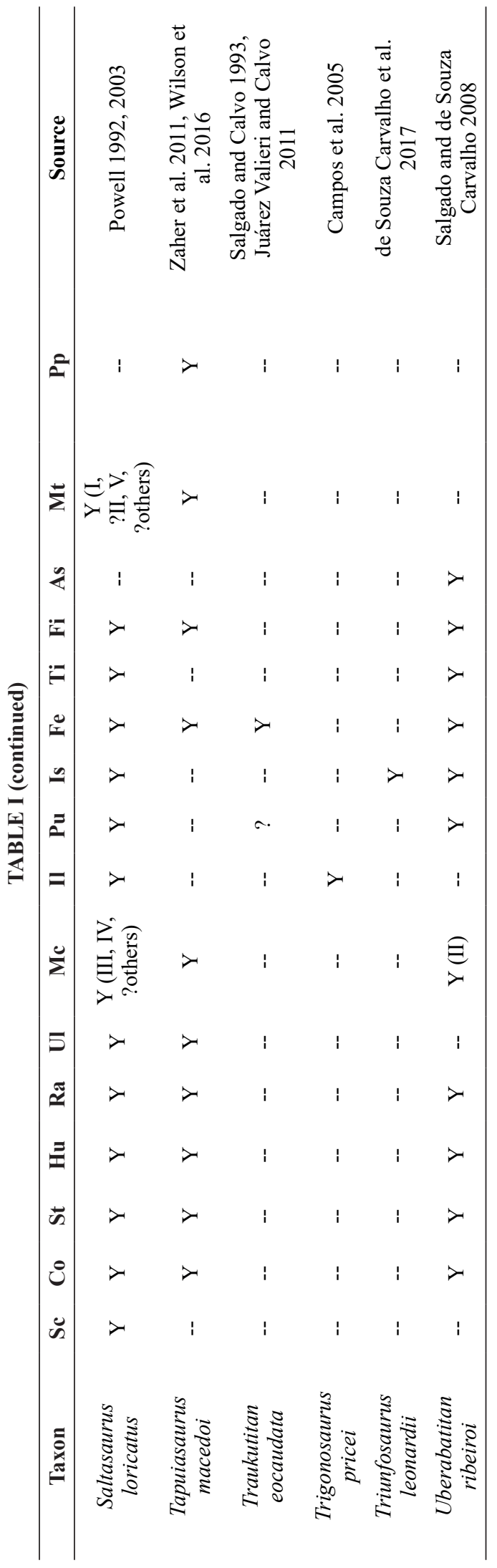

SCAPULA

Well-preserved scapulae are reported in Aeolosaurus rionegrinus (Powell 2003), Antarctosaurus wichmannianus (Huene 1929), Choconsaurus (Simón et al. 2018), Dreadnoughtus (Ullmann and Lacovara 2016), Elaltitan (Mannion and Otero 2012), Mendozasaurus (González Riga et al. 2018), Muyelensaurus (Calvo et al. 2007c), Neuquensaurus (Otero 2010), Patagotitan (Carballido et al. 2017), Pitekunsaurus (Filippi and Garrido 2008), and Saltasaurus (Powell 1992, 2003) among other South American titanosaurs (Table I, Figure 2). Additionally, although the scapula is poorly preserved in the type and only known specimen of Drusilasaura, its overall shape is evident (Navarrete et al. 2011).

As in non-titanosaurian sauropods, the proximal (i.e., anterior, if the long axis of the scapula is oriented horizontally) end of the scapula is more expanded than the distal (i.e., posterior) end. In most South American titanosaurs (e.g., Drusilasaura, Mendozasaurus, Patagotitan, Pitekunsaurus, Saltasaurus), the proximal expansion is less than twice the dorsoventral breadth of the distal end, with the exceptions of Dreadnoughtus and Muyelensaurus, in which the proximal end is more than twice as broad as the distal. Nevertheless, the scapulae of most South American titanosaurs also exhibit a slight distal expansion, with the dorsal (i.e., acromial) edge of the blade being dorsally deflected and the ventral edge remaining nearly straight. In most titanosaurs, however, the tallest part of the dorsal margin of the scapular blade is still lower than that of the proximal expansion. An exception is seen in Patagotitan, in which the most elevated point of the blade is approximately the same height as that of the proximal end (Figure 2h). Among South American titanosaurs, a reversal to an unexpanded distal scapular blade occurs in Dreadnoughtus, in which the dorsal and ventral 
edges of the blade are subparallel to one another (Figure 2d).

In some South American titanosaurs (e.g., Patagotitan, Pitekunsaurus), as in other members of the clade (e.g., Rapetosaurus), the orientation of the scapular blade relative to the coracoid articulation is roughly $45^{\circ}$. In other forms (e.g., Dreadnoughtus, Muyelensaurus), however, the long axes of the blade and coracoid articulation are oriented roughly perpendicular to one another. In titanosaurs, the acromial ridge is generally not as developed as it is in non-titanosaurian neosauropods such as Diplodocus (Hatcher 1901), Giraffatitan (Janensch 1961), or Camarasaurus (McIntosh et al. 1996), in which this ridge clearly delimits a proximal scapular fossa, widely regarded as the origin site of the M. supracoracoideus (Meers 2003, Otero 2018) (Figure 2m-o). In Patagotitan, Pitekunsaurus, and the recently described, probably basal titanosaur Choconsaurus, the acromial region grades much more smoothly into the scapular blade than is the case in some other taxa (e.g., Aeolosaurus rionegrinus, Dreadnoughtus, Elaltitan, Muyelensaurus). When examined in lateral view, the scapular blade is dorsoventrally deep in some taxa (e.g., A. rionegrinus, Patagotitan, Saltasaurus) but substantially shallower in others (e.g., Dreadnoughtus, Muyelensaurus). A ventromedial process on the ventral margin of the blade (sensu Carballido et al. 2011) is present in Dreadnoughtus, Elaltitan, Neuquensaurus, Patagotitan, and Saltasaurus, among other South American titanosaurs.

\section{CORACOID}

The coracoid is known in a minority of South American titanosaurs, including Choconsaurus, Dreadnoughtus, Epachthosaurus, Narambuenatitan (Filippi et al. 2011a), Neuquensaurus, Patagotitan, Quetecsaurus (González Riga and Ortiz David 2014),
Rinconsaurus (Calvo and González Riga 2003), Saltasaurus, Tapuiasaurus, and Uberabatitan (Table I, Figure 3a-c, e). In Titanosauria, the proximodistal (i.e., anteroposterior, if the long axis of the scapulocoracoid is oriented horizontally) length of the coracoid may be up to twice the length of the scapular articulation. The coracoid was progressively modified through the evolution of Saltasauridae, increasing in proximodistal elongation, becoming 'squared' at its anteroventral margin, and ultimately extending to the height of the acromial process (i.e., attaining a flush suture with the scapula). These derived morphologies are reported in many South American titanosaurs, such as the saltasaurines Neuquensaurus and Saltasaurus and the lognkosaurian Quetecsaurus, and are shared with some Asian titanosaurs (e.g., Opisthocoelicaudia, ZPAL MgD-I/48, BorsukBialynicka 1977) and the North American Alamosaurus (USNM 15560, Gilmore 1946) as well. An infraglenoid lip is present in most or all South American titanosaurs for which the coracoid is preserved. The position of the coracoid foramen varies among South American titanosaurs, being situated immediately adjacent to the scapular articulation in some taxa (e.g., Quetecsaurus, Figure 3c) but located further from this articulation in others (e.g., Saltasaurus, Figure 3b). Nevertheless, as the position of the coracoid foramen appears to change through neosauropod ontogeny (see, e.g., Ullmann and Lacovara 2016), these distinctions are probably of limited taxonomic and phylogenetic significance.

STERNUM

Sternal plates are reported with some frequency among South American titanosaurs, being known in Bonitasaura (Gallina and Apesteguía 2015), Choconsaurus, Dreadnoughtus, Epachthosaurus, Maxakalisaurus (Kellner et al. 2006), Mendozasaurus, Muyelensaurus, 

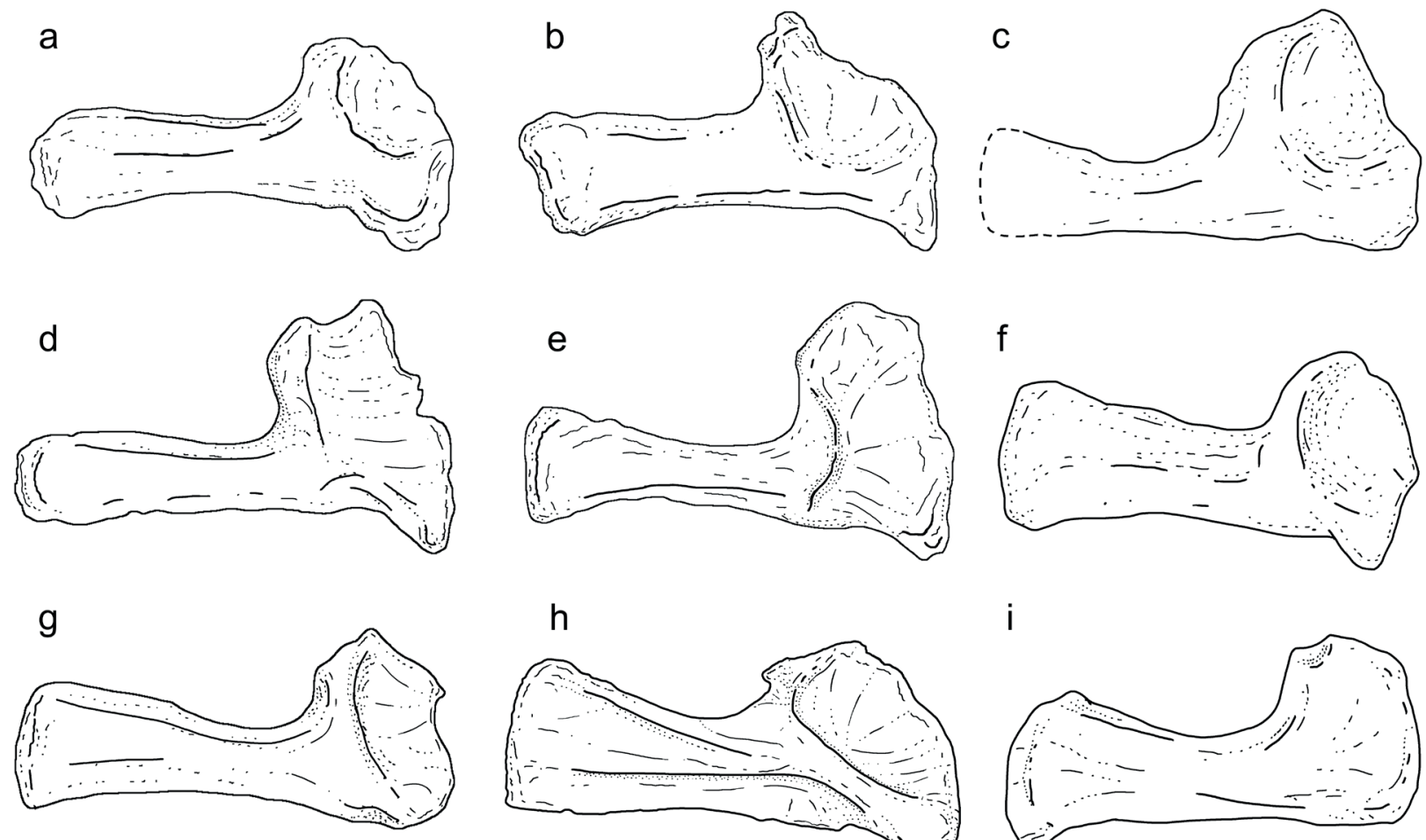

$\mathrm{h}$

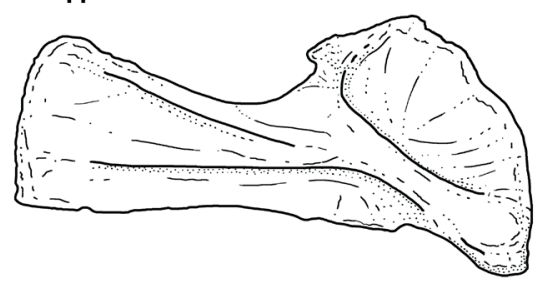

i
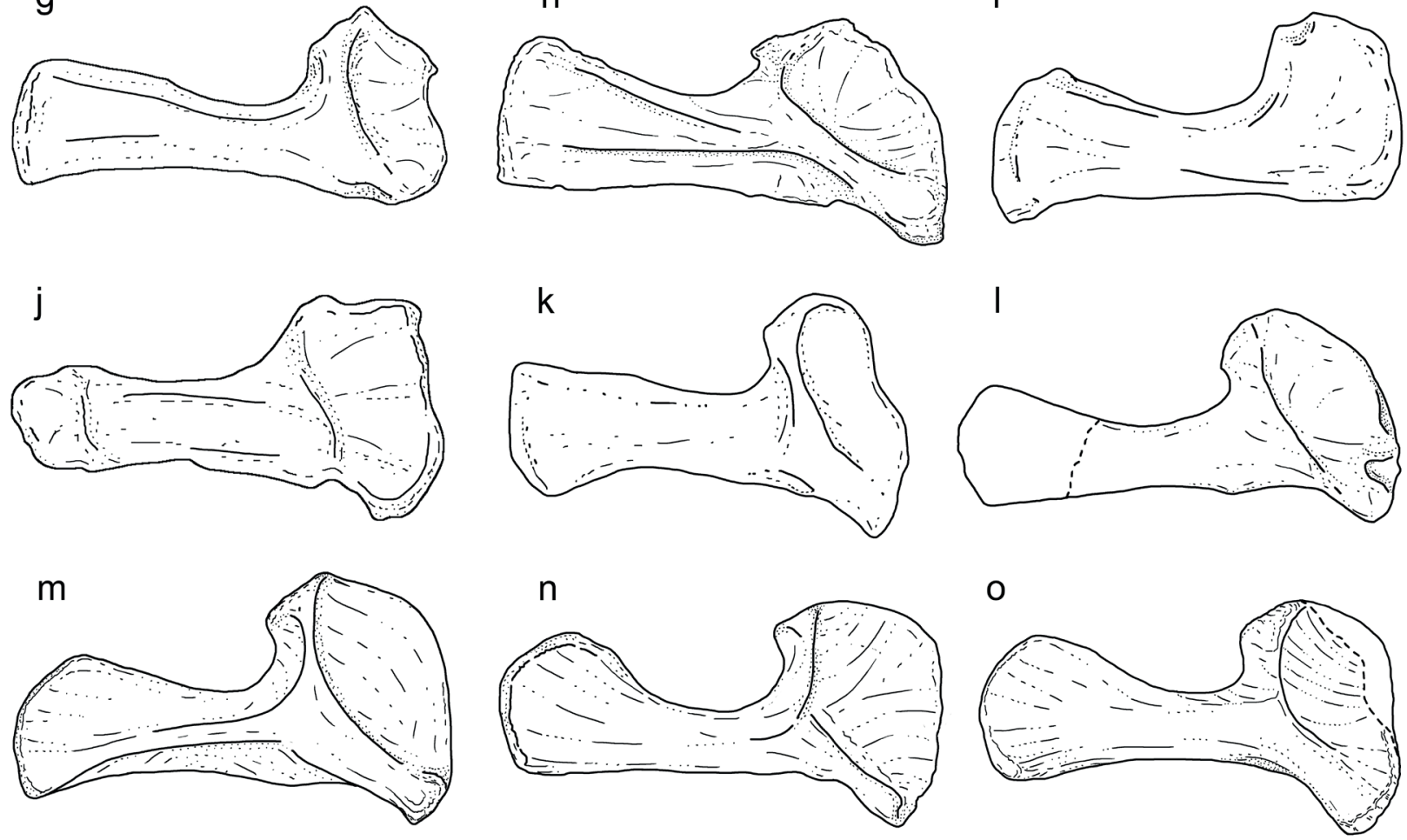

Figure 2 - Morphological comparison of right scapulae of titanosaurians (a-k) versus those of other sauropods (l-o) in lateral view. South American (Argentinean) taxa denoted with an asterisk. (a) Pitekunsaurus macayai*, redrawn from Filippi and Garrido (2008), (b) Rapetosaurus krausei, redrawn from Curry Rogers (2009), (c) Choconsaurus baileywillisi*, redrawn from Simón et al. (2018), (d) Dreadnoughtus schrani* (left, reversed), redrawn from Lacovara et al. (2014), (e) Muyelensaurus pecheni*, redrawn from Calvo et al. (2007c), (f) Saltasaurus loricatus*, redrawn from Powell (1992), (g) Mendozasaurus neguyelap*, redrawn from González Riga et al. (2018), (h) Patagotitan mayorum*, redrawn from Carballido et al. (2017), (i) Drusilasaura deseadensis* (reversed), redrawn from Navarrete et al. (2011), (j) Opisthocoelicaudia skarzynskii, redrawn from Borsuk-Bialynicka (1977), (k) Elaltitan lilloi*, redrawn from Mannion and Otero (2012), (I) Mamenchisaurus youngi (left, reversed), redrawn from Ouyang and Ye (2002), (m) Diplodocus carnegii (left, reversed), redrawn from Hatcher (1901), (n) Giraffatitan brancai (left, reversed), redrawn from Janensch (1961), (o) Camarasaurus supremus (left, reversed), redrawn from Osborn and Mook (1921). Not to scale. 
Narambuenatitan, Neuquensaurus, Patagotitan, Petrobrasaurus (Filippi et a1. 2011b), Rinconsaurus, Saltasaurus, Tapuiasaurus, and Uberabatitan (Table I, Figure $3 \mathrm{f}-\mathrm{k}$ ). Unlike those of non-titanosaurian sauropods (e.g., the brachiosaurid Giraffatitan) the sternal plates of titanosaurs are generally semilunate in shape and at least $65-70 \%$ the length of the humerus (McIntosh 1990, Salgado et al. 1997, Upchurch 1998, D'Emic 2012, Mannion et al. 2013). Nevertheless, the sternal plates of Choconsaurus and Mendozasaurus are less mediolaterally expanded at their posterior ends than are those of some other titanosaurs (e.g., Dreadnoughtus, Maxakalisaurus, Narambuenatitan, Petrobrasaurus, probably Tapuiasaurus), rendering them more subtriangular than semilunate in dorsal or ventral view (Figure 3f, g). This shape, with some variation, was described as a semilunar sternal plate with a relatively straight posterior border by González Riga (2003) and González Riga and Ortiz David (2014). Similarly, there is considerable variation in the lateral projection of the anterior and posterior ends - and therefore the concavity of the lateral margin — of the sternal plate between different South American titanosaurian genera. In Choconsaurus and Mendozasaurus, the lateral margin is only slightly concave in dorsal view, whereas in taxa such as Maxakalisaurus, Saltasaurus, and especially Narambuenatitan this margin is deeply concave; forms such as Dreadnoughtus, Petrobrasaurus, Rinconsaurus, and Tapuiasaurus appear to exhibit an intermediate condition (Figure $3 \mathrm{f}-\mathrm{k}$ ). There is a ridge on the ventral surface of the sternal plate in Bonitasaura, Dreadnoughtus, Neuquensaurus, Patagotitan, and Saltasaurus, among other taxa.

\section{HUMERUS}

The humerus is the most frequently preserved appendicular bone among South American titanosaurian taxa, being known in 27 valid species at present (Table I). It is highly variable in proportions, ranging from slender in taxa such as Gondwanatitan (Kellner and de Azevedo 1999), Mendozasaurus, Panamericansaurus (Calvo and Porfiri 2010), Petrobrasaurus, Rinconsaurus, and especially Muyelensaurus, in which the proximal and distal ends are not markedly expanded, to exceedingly robust as in Dreadnoughtus and saltasaurines (Figure 4). For example, the humeral robustness index (sensu Wilson and Upchurch 2003) of Muyelensaurus is 0.18 , whereas in specimens of the saltasaurine Neuquensaurus (e.g., MLP-CS 1049) this index may reach values of up to 0.32. In some South American titanosaurs (e.g., Argyrosaurus, Atacamatitan [Kellner et al. 2011], Bonatitan [Martinelli and Forasiepi 2004, Salgado et al. 2015], Futalognkosaurus [Calvo, 2014], Elaltitan, Mendozasaurus, Muyelensaurus, Narambuenatitan, Neuquensaurus, Uberabatitan), the proximal margin of the humerus is straight, or nearly so, in anterior view (e.g., Figure 4a, c). In other titanosaurs, however (e.g., Notocolossus [González Riga et al. 2016], Opisthocoelicaudia, Paralititan, Quetecsaurus, Saltasaurus), the proximal margin of the humerus is sinuous due to the marked proximal deflection of the humeral head relative to the remainder of the bone (Figure $4 \mathrm{j}$ ). The lateral margin of the humerus is nearly straight through approximately the proximal half of the element. Futalognkosaurus has a relatively robust humerus with an expanded proximal end that reaches $40 \%$ of the total length of the bone, as in Saltasaurus, Neuquensaurus, and Opisthocoelicaudia (Calvo 2014).

Thehumeriofmany SouthAmerican titanosaurs (e.g., the saltasaurines Neuquensaurus and Saltasaurus, the lognkosaurian Futalognkosaurus [Calvo 2014], Patagotitan, and Dreadnoughtus) possess a well-developed posterolateral bulge around the level of the deltopectoral crest, which is frequently regarded as the insertion site of the M. deltoideus clavicularis (Meers 2003, Otero 2018). 
a

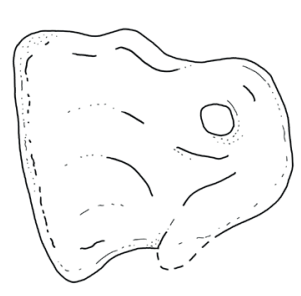

b

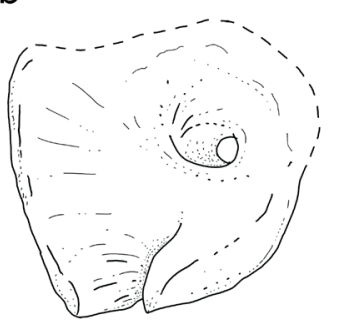

C

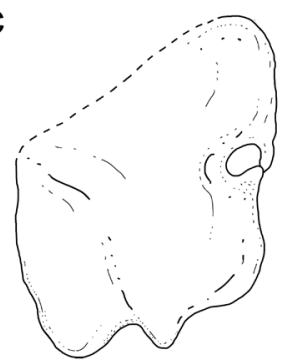

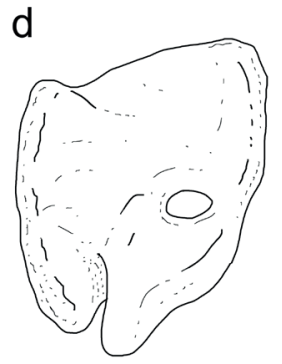

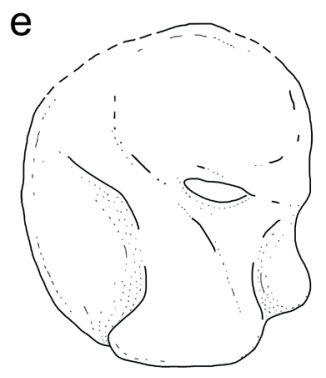

f

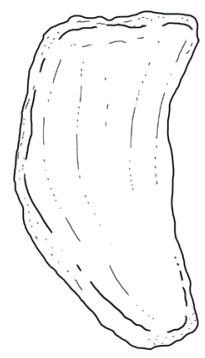

g

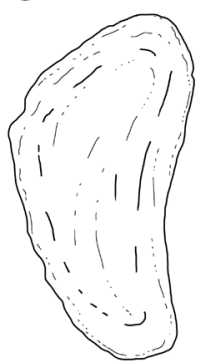

h

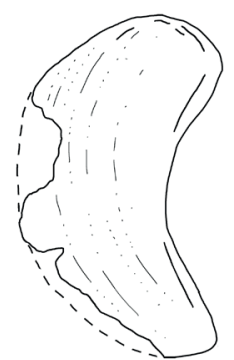

i

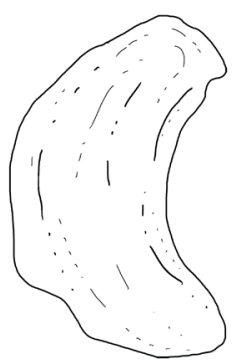

j

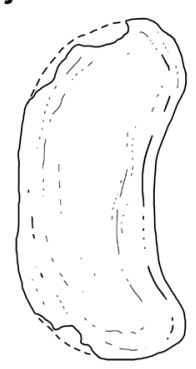

k

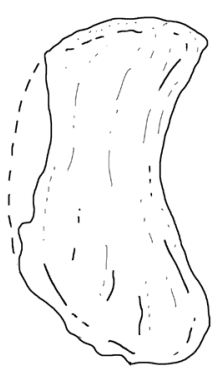

Figure 3 - Morphological comparison of titanosaurian coracoids (a-e) and sternal plates (f-k). South American (Argentinean) taxa denoted with an asterisk. (a) Right coracoid in medial view of Neuquensaurus australis*, MLP-Ly 14, redrawn from Otero (2010), (b) left coracoid in lateral view of Saltasaurus loricatus*, PVL 4017-100, redrawn from Powell (1992), (c) right coracoid in medial view of Quetecsaurus rusconii*, UNCUYO-LD 300.15, redrawn from González Riga and Ortiz David (2014), (d) left coracoid in lateral view of Opisthocoelicaudia skarzynskii, ZPAL MgD-I/48, redrawn from Borsuk-Bialynicka (1977), (e) left coracoid in lateral view of Dreadnoughtus schrani*, MPM-PV 1156, redrawn from Ullmann and Lacovara (2016), (f) right sternal plate in dorsal view of Mendozasaurus neguyelap*, IANIGLA-PV 067, redrawn from González Riga et al. (2018), (g) right sternal plate in dorsal view of Choconsaurus baileywillisi*, MMCh-Pv 44/11, redrawn from Simón et al. (2018), (h) left sternal plate in ventral view of Saltasaurus loricatus*, PVL 4017-102, redrawn from Powell (1992), (i) left sternal plate in ventral view of Narambuenatitan palomoi*, MAU-Pv-N-425, redrawn from Filippi et al. (2011a), (j) left sternal plate in ventral view of Dreadnoughtus schrani*, MPM-PV 1156, redrawn from Ullmann and Lacovara (2016), (k) left sternal plate in ventral view of Petrobrasaurus puestohernandezi*, MAU-Pv-N-449/25, redrawn from Filippi et al. (2011b). Not to scale.

Unlike many other South American titanosaurs, Neuquensaurus and Saltasaurus also exhibit a deltopectoral crest that is markedly expanded distally, a feature that is shared with the Laurasian titanosaurs Alamosaurus and Opisthocoelicaudia and that consequently has been regarded as a synapomorphy of Saltasauridae (Wilson 2002, D’Emic 2012). South American titanosaurs also exhibit variability in features such as the distal extent and medial deflection of the deltopectoral crest, the development of a proximolateral process, and the concavity of the medial margin of the shaft in anterior view. In saltasaurines and other lithostrotians (e.g., the non-South American genera
Alamosaurus, Isisaurus, Opisthocoelicaudia, and Rapetosaurus), the articular surfaces of the humeral distal condyles are exposed on the anterior surface of the bone. The humeral distal condyles of titanosaurs are generally flat, except in saltasaurids and Epachthosaurus in which they are divided.

The longest humerus known for any titanosaur is that of the holotypic specimen of Notocolossus (UNCUYO-LD 301, Figures 1c, 4j, González Riga et al. 2016). This bone is even longer and more proximally robust than the humerus of Patagotitan (Figure $4 \mathrm{~h}$ ), a titanosaur that was recently described as the largest dinosaur yet discovered (Carballido et al. 2017). The humerus of Notocolossus is also 


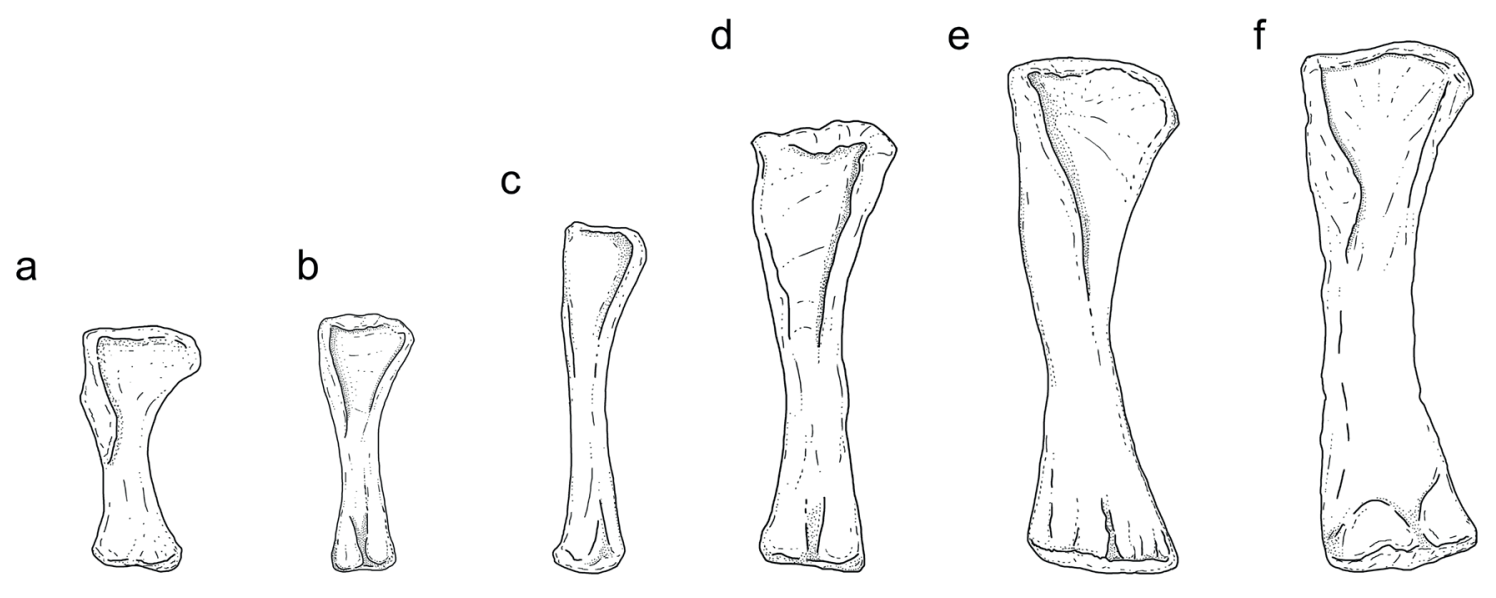

g

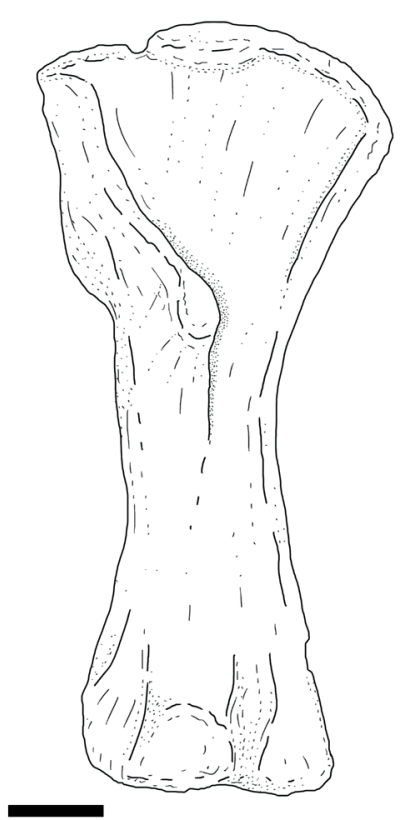

h

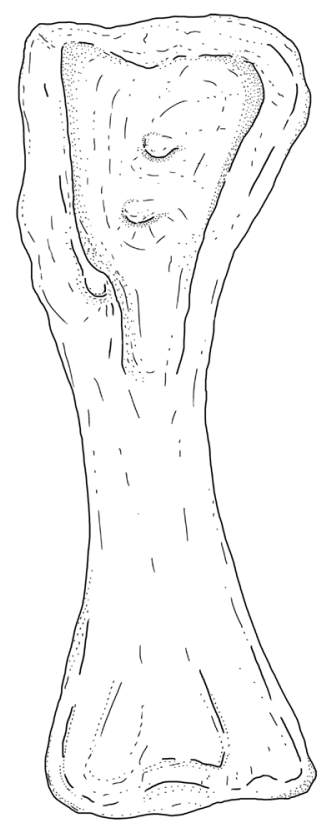

i

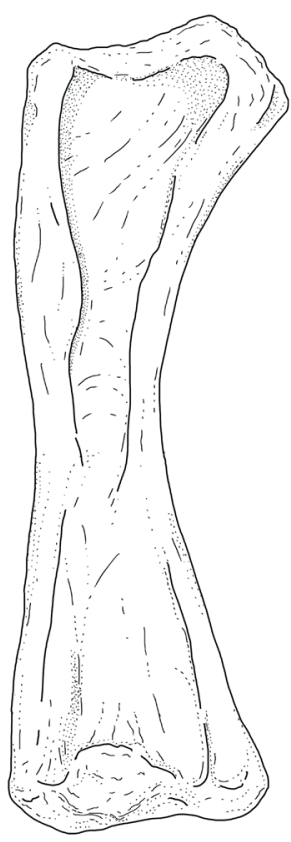

j

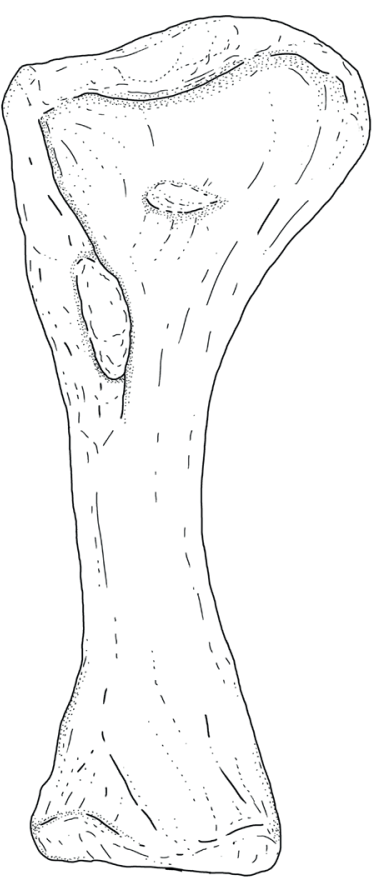

Figure 4 - Morphological and size comparison of titanosaurian right humeri in anterior view. South American (Argentinean) taxa marked with an asterisk. (a) Neuquensaurus australis* (left, reversed), redrawn from Otero (2010), (b) Rapetosaurus krausei (left, reversed), redrawn from Curry Rogers (2009), (c) Muyelensaurus pecheni* (left, reversed), redrawn from Calvo et al. (2007c), (d) Narambuenatitan palomoi* (left, reversed), redrawn from Filippi et al. (2011a), (e) Mendozasaurus neguyelap*, redrawn from González Riga et al. (2018), (f) Angolatitan adamastor, redrawn from Mateus et al. (2011), (g) Dreadnoughtus schrani* (left, reversed), redrawn from Lacovara et al. (2014), (h) Patagotitan mayorum* (left, reversed), redrawn from Carballido et al. (2017), (i) Paralititan stromeri, redrawn from Smith et al. (2001), (j) Notocolossus gonzalezparejasi*, redrawn from González Riga et al. (2016). Scale bar equals $20 \mathrm{~cm}$. 
longer than those of other giant titanosaurs such as Dreadnoughtus (Figure 4g, Lacovara et al. 2014), Futalognkosaurus (Calvo 2014), and Paralititan (Figure 4i, Smith et al. 2001). Therefore, despite the incomplete nature of the known remains, Notocolossus is likely among the largest titanosaurs discovered thus far. Nevertheless, we recommend caution when estimating the body size of one gigantic titanosaurian taxon versus another. Accurate estimation of body size (e.g., total length, mass, volume) is highly problematic in the largest titanosaurs because, with the exceptions of Dreadnoughtus, Futalognkosaurus, and Patagotitan, most of these taxa (e.g., 'Antarctosaurus' giganteus, Argentinosaurus, Paralititan, Puertasaurus, Notocolossus) are represented by very incomplete skeletons (Lacovara et al. 2014). Moreover, given the morphological disparity seen in relatively complete, smallerbodied titanosaurs (e.g., Diamantinasaurus, Epachthosaurus, Isisaurus, Mendozasaurus, Opisthocoelicaudia, Rapetosaurus, Saltasaurus), it is probable that different gigantic species also had markedly different anatomical proportions, such as the relative proportions and robusticity of the limb elements, the lengths of the cervical and caudal series, and the distance from the glenoid to the acetabulum. Indeed, this contention has already been borne out, at least to some degree, by the substantially different humeral proportions of the giant titanosaurs Dreadnoughtus, Notocolossus, Paralititan, and Patagotitan (Figure 4g-j), with Notocolossus and especially Dreadnoughtus possessing exceedingly robust humeri, that of Paralititan being more slender, and that of Patagotitan exhibiting an intermediate condition. Although issues surrounding body size estimation in the largest titanosaurs have been partly ameliorated by recent discoveries of relatively complete skeletons of Dreadnoughtus, Futalognkosaurus, and Patagotitan, additional, similarly complete giant titanosaur specimens will be needed to definitively assess the widely varying dimensions postulated in recent works (e.g., Lacovara et al. 2014, Bates et al. 2015, González Riga et al. 2016, Carballido et al. 2017).

\section{RADIUS AND ULNA}

Both the radius and ulna are known in the South American titanosaurs Aeolosaurus rionegrinus, Argyrosaurus, Bonitasaura, Dreadnoughtus, Elaltitan, Epachthosaurus, Mendozasaurus, Muyelensaurus, Neuquensaurus, Patagotitan, Quetecsaurus, Saltasaurus, and Tapuiasaurus, the former bone is additionally known in Uberabatitan and the latter in Narambuenatitan and Pitekunsaurus (Table I). With the exceptions of a few taxa (e.g., Dreadnoughtus, Elaltitan) the distal mediolateral breadth of the radius is approximately twice its breadth at midshaft. In saltasaurid titanosaurs (and probably some other neosauropods, Upchurch et al. 2015), the distal radius is also beveled approximately $20^{\circ}$ proximolaterally relative to the long axis of the shaft (Wilson 2002, D'Emic 2012).

Most lithostrotians exhibit a proximally elevated olecranon process of the ulna, which constitutes a reversal to the basal sauropodomorph condition (Wilson and Sereno 1998, Galton and Upchurch 2004, Mannion et al. 2013). The ulnae of saltasaurid titanosaurs are further characterized by their stout proportions (Wilson 2002); this condition is developed to an extreme in the saltasaurines Neuquensaurus and Saltasaurus. Most other titanosaurs have more gracile ulnae, a condition that is especially true for taxa such as Mendozasaurus and Narambuenatitan. In titanosaurs, and sauropods in general, the anteromedial process of the proximal ulna is usually longer than the anterolateral process.

\section{CARPUS AND MANUS}

With the possible exceptions of the carpal elements reported in Argyrosaurus and Neuquensaurus, 
but currently lost (Lydekker 1893, Huene 1929, Otero 2010, Mannion and Otero 2012), titanosaurs appear to lack an ossified carpus (Upchurch 1998, Wilson 2002, D'Emic 2012). The metacarpus is completely or nearly completely known in several South American titanosaurian taxa (Aeolosaurus rionegrinus, Antarctosaurus wichmannianus, Argyrosaurus, Choconsaurus, Epachthosaurus, Mendozasaurus, Quetecsaurus, and Rinconsaurus) and partially preserved in a few others (Table I, Figure 5). A number of these forms (e.g., $A$. rionegrinus, saltasaurines) have fairly stout metacarpals, but in Argyrosaurus (Mannion and Otero 2012) and especially Choconsaurus (Simón et al. 2018) these bones are more elongate and slender, as is also the case in Andesaurus, for which only metacarpals I and V are represented (Calvo and Bonaparte 1991, Mannion and Calvo 2011). In many titanosaurs, the ratio of the proximodistal length of metacarpal I to that of metacarpal II or III is 1.0 or greater (Upchurch 1998, Mannion et al. 2013); also, the proximal end of metacarpal $\mathrm{V}$ is often subequal in size to that of metacarpal I (D'Emic 2012). Nevetheless, in taxa such as Choconsaurus, Epachthosaurus, and Quetecsaurus, the proximal end of metacarpal $\mathrm{V}$ is clearly smaller than that of metacarpal I, with the latter being much more anteroposteriorly elongate (Figure 5b).

Multiple authors have argued that, in Titanosauria or clades therein, most or even all manual phalanges were absent or unossified (e.g., Salgado et al. 1997, Wilson 2002, Apesteguía 2005, Curry Rogers 2005). Among South American titanosaurs, this contention is supported by the condition in Argyrosaurus, which is known from a complete, articulated forelimb that nonetheless lacks direct evidence of manual phalanges (Mannion and Otero 2012) (but see Discussion below). Similarly, an exceptionally complete, articulated postcranium of Epachthosaurus (UNPSJB-PV 920) possesses only a single rudimentary phalanx on manual digit IV (Martínez et al. 2004); an identical condition occurs in the holotypic skeleton of the Mongolian titanosaur Opisthocoelicaudia (ZPAL MgD-I/48, Borsuk-Bialynicka 1977). Nevertheless, manual phalanges are well-documented in the Australian titanosaurs Diamantinasaurus and Savannasaurus (Hocknull et al. 2009, Poropat et al. 2015, 2016), indicating that the diversity of manual morphologies within Titanosauria was almost certainly greater than is presently appreciated (see Discussion).

\section{THE PELVIC AND HIND LIMB SKELETON OF SOUTH AMERICAN TITANOSAURS}

ILIUM

The titanosaurian ilium exhibits remarkable features. The bone is at least partially preserved in many South American taxa, including Antarctosaurus wichmannianus (Huene 1929, Powell 2003), Brasilotitan (Machado et al. 2013), Dreadnoughtus (Lacovara et al. 2014, Ullmann and Lacovara 2016), Epachthosaurus (Martínez et al. 2004), Futalognkosaurus (Calvo et al. 2007a, b), Gondwanatitan (Kellner and de Azevedo 1999), Muyelensaurus (Calvo et al. 2007c), Narambuenatitan (Filippi et al. 2011a), Neuquensaurus (Salgado et al. 2005, Otero 2010), Overosaurus (Coria et al. 2013), Petrobrasaurus (Filippi et al. 2011b), Rinconsaurus (Calvo and González Riga 2003), Rocasaurus (Salgado and Azpilicueta 2000), Saltasaurus (Powell 1992, 2003), and Trigonosaurus (Campos et al. 2005) (Table I). Among these taxa, the largest complete ilia and sacrum belong to Futalognkosaurus. In titanosaurs, the pre- and postacetabular processes of the ilium are expanded anteroposteriorly and dorsoventrally (Otero and Vizcaíno 2008, Otero 2010). Although lateral projection of the iliac preacetabular process characterizes titanosaurs as a whole, the orientation of this process (i.e., lateral or anterolateral) varies considerably among titanosaurian taxa (Figure 6a, b). For example, the lateral projection of the preacetabular process 

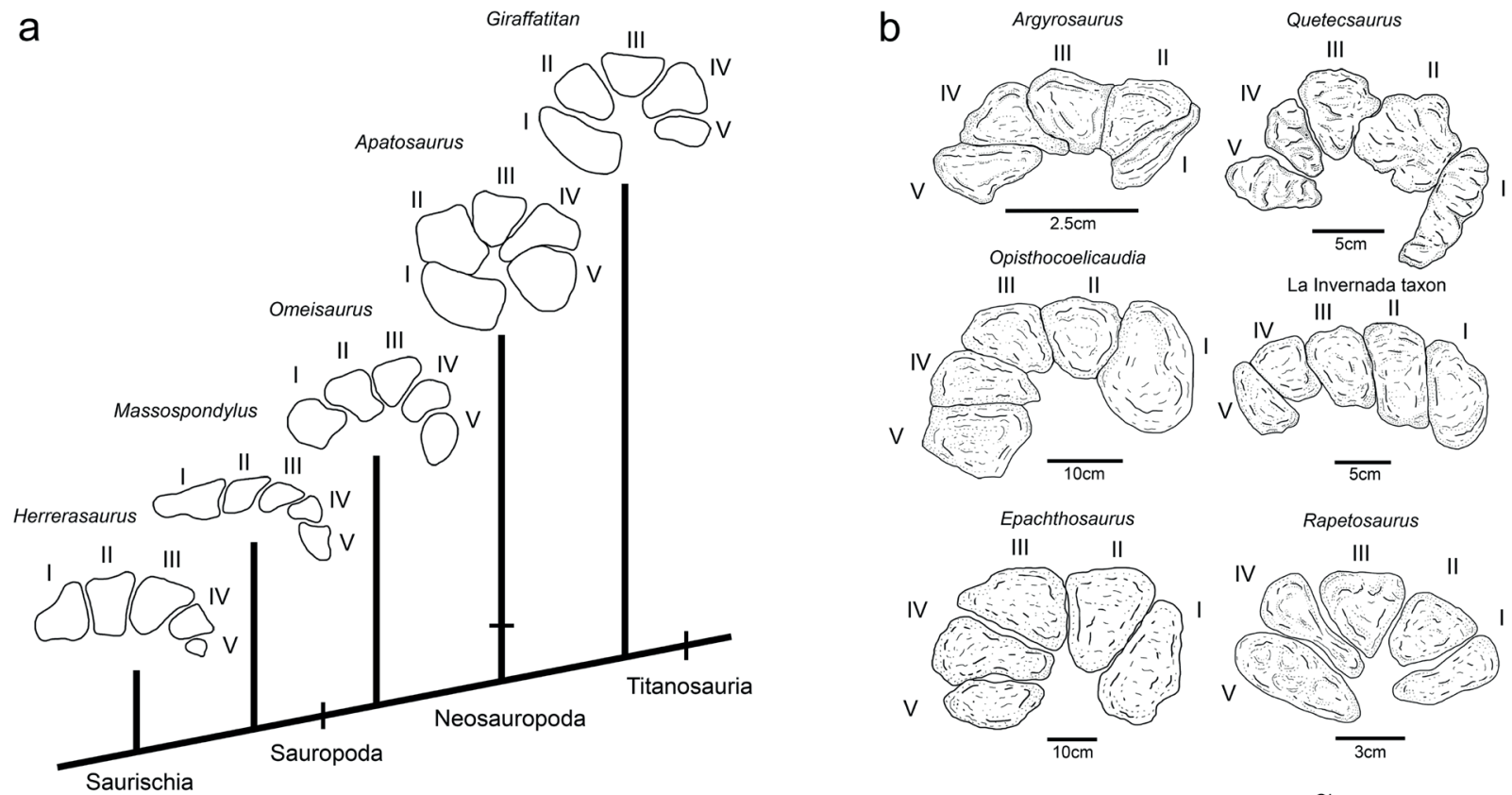

Saurischia

C

Epachthosaurus

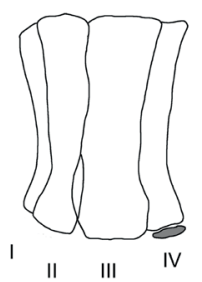

Argyrosaurus

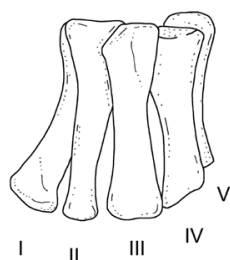

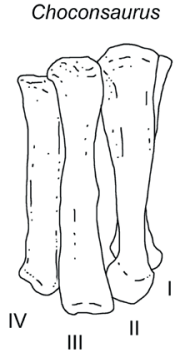

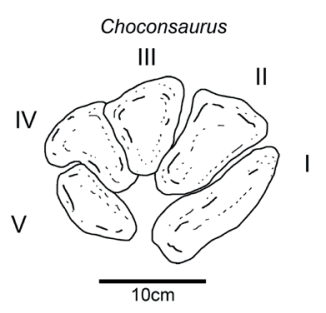

Figure 5 - (a) Simplified phylogenetic diagram of right metacarpus shape in proximal view in non-titanosaurian Sauropodomorpha and Herrerasaurus, modified from Bonnan (2003). The name Brachiosaurus has been replaced by Giraffatitan. Not to scale. (b) Comparison of left metacarpus of selected titanosaurs in proximal view. Argyrosaurus redrawn from Mannion and Otero (2012), Quetecsaurus redrawn from González Riga and Ortiz David (2014), Opisthocoelicaudia redrawn from Borsuk-Bialynicka (1977), La Invernada taxon drawn from personal observation of MUCPv-1533, Epachthosaurus redrawn from Martínez et al. (2004), Rapetosaurus redrawn from Curry Rogers (2009), Choconsaurus redrawn from Simón et al. (2018). Not to scale. (c) Right metacarpus (anterior view) of Epachthosaurus (with phalanx IV-1 in dark gray) and Argyrosaurus, redrawn and modified from Apesteguía (2005), and left metacarpus (anterior view) of Choconsaurus, redrawn from Simón et al. (2018). Roman numerals indicate metacarpal number. Not to scale.

is more pronounced in Futalognkosaurus, Neuquensaurus (Figure 6a), and Saltasaurus than it is in Dreadnoughtus, Epachthosaurus, Overosaurus (Figure 6b), or Trigonosaurus. To more rigorously define this character, Salgado et al. (2005) proposed an estimate of the ratio between the distance of the lateralmost point of the pubic peduncle versus that of the preacetabular process. A strongly laterally directed preacetabular process appears to be associated with elongation of the sacral ribs, as seen in, for example, Neuquensaurus (MCS-5/16, B.J.G.R. pers. obs.).

In some South American titanosaurs (e.g., Overosaurus, Rinconsaurus), the portion of the iliac blade dorsal to the pubic peduncle is dorsoventrally deep, whereas in others (e.g., Saltasaurus) it is much shallower. Furthermore, ihe ilia of saltasaurines exhibit a 'kink' on the 
ventral margin of the preacetabular process (D'Emic 2012). These morphological changes are probably related to locomotor specializations (Wilson and Carrano 1999) and/or the attachment of pelvic musculature (Otero and Vizcaíno 2008). As in Sauropoda more generally, the ischial peduncle of the titanosaurian ilium is only slightly developed (Wilson 2002), and in derived taxa such as saltasaurines, it is often confluent with the remainder of the bone. Conversely, the pubic peduncle is elongate, relatively gracile, and anteroventrally projected. Interestingly, the ilia of multiple titanosaurs, including South American forms such as Dreadnoughtus (Ullmann and Lacovara 2016), Epachthosaurus (Martínez et al. 2004), and Neuquensaurus (Cerda et al. 2012), display well-developed internal camerae, indicating that they were probably pneumatized by diverticula from the respiratory system. Conversely, the ilia of some other titanosaurs (e.g., the Tanzanian basal form Rukwatitan, Gorscak et al. 2014) appear to have been apneumatic.

PUBIS

Among South American titanosaurs, the pubis is at least partially preserved in Andesaurus, Antarctosaurus wichmannianus, 'Antarctosaurus' giganteus (Huene 1929), Bonitasaura, Dreadnoughtus, Elaltitan, Epachthosaurus, Futalognkosaurus, Gondwanatitan, Mendozasaurus, Muyelensaurus, Narambuenatitan, Neuquensaurus, Notocolossus, Patagotitan, Petrobrasaurus, Rinconsaurus, Rocasaurus, Saltasaurus, and Uberabatitan (Table I, Figure 6c-f). In most of these taxa (e.g., Andesaurus, Elaltitan, Futalognkosaurus), it is a short, stout bone, but the pubic blade is slenderer in a few other forms (e.g., Muyelensaurus, Petrobrasaurus). The iliac articular surface of the pubis is anteroposteriorly elongate in titanosaurs (Mannion et al. 2013). The obturator foramen is subcircular in many titanosaurs but oval in Andesaurus, Futalognkosaurus, and Muyelensaurus (Mannion and Calvo 2011). The pubes of several titanosaurs (e.g., Dreadnoughtus, Futalognkosaurus) exhibit a longitudinal ventrolateral ridge that is most strongly developed in taxa such as Neuquensaurus, Saltasaurus, and Uberabatitan.

According to many phylogenetic studies (e.g., Salgado et al. 1997), a typical titanosaurian character is the presence of a pubis that is proximodistally longer than the ischium. This feature seems to be present in most or even all titanosaurs, but in taxa such as Futalognkosaurus, it is developed to an extreme, with the pubis being markedly longer and more robust than the ischium (Figure 6f). Furthermore, in this massive Patagonian titanosaur, the bone has a slightly subcircular and expanded distal end and is strongly thickened distally (MUCPv-323, B.J.G.R. pers. obs.). The pubis of the basal titanosaur Andesaurus possesses a proximodistally elongate ischial articulation (Figure 6e); in most other titanosaurian taxa, by contrast, this articular surface is shorter.

\section{ISCHIUM}

The ischium is known in many South American titanosaurs, being especially well-preserved in taxa such as Andesaurus, Bonitasaura, Dreadnoughtus, Futalognkosaurus, Muyelensaurus, and Saltasaurus (Table I, Figure 6c-f). The titanosaurian ischium is a short bone with a relatively broad, plate-like blade (Salgado et al. 1997, Otero 2010); this morphology as well as the absence of emargination distal to the pubic articulation are typical of the clade (Wilson 2002, Díez Díaz et al. 2016). A mediolaterally compressed iliac articular surface also appears to be a titanosaurian character (Mannion and Calvo 2011). The pubic peduncle is anteroposteriorly elongate in forms such as Aeolosaurus rionegrinus, Antarctosaurus 
wichmannianus, and Muyelensaurus (Figure 6d), but shorter in others (e.g., Andesaurus [Figure 6e], Rinconsaurus, Saltasaurus, Triunfosaurus [de Souza Carvalho et al. 2017]). In many titanosaurian taxa, the acetabular margin of the ischium is strongly concave in lateral view, such that the pubic articular surface forms a proximodorsal projection (D'Emic 2012, Mannion et al. 2013, Figure 6d). The ischial blade is slender in taxa such as $A$. rionegrinus, Andesaurus, Bonitasaura, Futalognkosaurus, Gondwanatitan, and Muyelensaurus compared to the condition in other forms such as Rinconsaurus and the saltasaurines Rocasaurus and Saltasaurus.

\section{FEMUR}

The femur is at least partially preserved in 25 species of South American titanosaurs; after the humerus, it is the most frequently recovered appendicular bone of these sauropods (Table I, Figure 7). The femur is remarkably slender in Atacamatitan (Figure 7a), and to a lesser degree in 'Antarctosaurus' giganteus (Figure 7j), Bonatitan (Figure 7k), Mendozasaurus (Figure 7g), Patagotitan (Figure 7h), Petrobrasaurus (Figure 7f), and Rinconsaurus (Calvo and González Riga 2003, fig. $3 \mathrm{c}$ ), but considerably more robust in taxa such as Dreadnoughtus (Figure 7i), Futalognkosaurus (Calvo 2014), and the saltasaurines Neuquensaurus (Figure 7b, c), Rocasaurus (Salgado and Azpilicueta 2000, fig. 9a), and Saltasaurus (Figure 7e); titanosaurs such as Epachthosaurus (Figure 7d) and Traukutitan (Figure 7l) exhibit an intermediate condition. As with the humerus (see above), the markedly differing robusticities of the femur in giant titanosaurs such as 'A.' giganteus, Dreadnoughtus, and Patagotitan are relevant in discussions of the overall body dimensions of these taxa, though the significance of these differences for mass estimation is not yet completely clear. The femoral head is canted strongly proximomedially in Aeolosaurus maximus (Santucci and de
Arruda-Campos 2011), Bonitasaura (Gallina and Apesteguía 2015), and Rinconsaurus, but noticeably less so in taxa such as Bonatitan, Dreadnoughtus, Epachthosaurus, Patagotitan, Petrobrasaurus, and saltasaurines. In most South American titanosaurs, the proximal one third of the femur is angled strongly medially relative to the remainder of the shaft, but a few taxa (e.g., Epachthosaurus, Figure 7d) lack this morphology (Mannion et al. 2013). Most South American titanosaurs (e.g., Bonatitan, Dreadnoughtus, Patagotitan, Petrobrasaurus, Traukutitan, saltasaurines) also have a prominent lateral bulge on the proximal third of the femur distal to the greater trochanter. This feature was initially recognized by McIntosh (1990) and regarded by Salgado et al. (1997) as a synapomorphy of their then-newly defined clade Titanosauriformes; it is also present but less developed in some nontitanosauriform taxa (Mannion et al. 2013). Salgado et al. (1997, fig. 10) tentatively quantified the presence of the lateral bulge as being $30 \%$ the minimum mediolateral width of the femoral shaft.

In South American titanosaurs, the femoral shaft is anteroposteriorly compressed, rendering it elliptical in cross section. The fourth trochanter is positioned near midshaft in some taxa (e.g., Antarctosaurus wichmannianus, 'A.' giganteus, Bonitasaura, Dreadnoughtus, Epachthosaurus, Mendozasaurus) but more proximally in others (e.g., Elaltitan, Neuquensaurus, Patagotitan). It is also more prominent in taxa such as Dreadnoughtus (Ullmann and Lacovara 2016) and Patagotitan (Carballido et al. 2017) than it is in others such as saltasaurines (e.g., Figure 7b, e). Saltasaurines exhibit a longitudinal ridge on the anterior surface of the femoral shaft (Otero 2010, D’Emic 2012). Another important femoral character is the orientation of the long axis of the distal condyles in anterior or posterior view; in many South American titanosaurs, the distal condyles are beveled $10^{\circ}$ dorsomedially (Wilson 2002, 2006, D'Emic 2012), though there are exceptions to this condition 

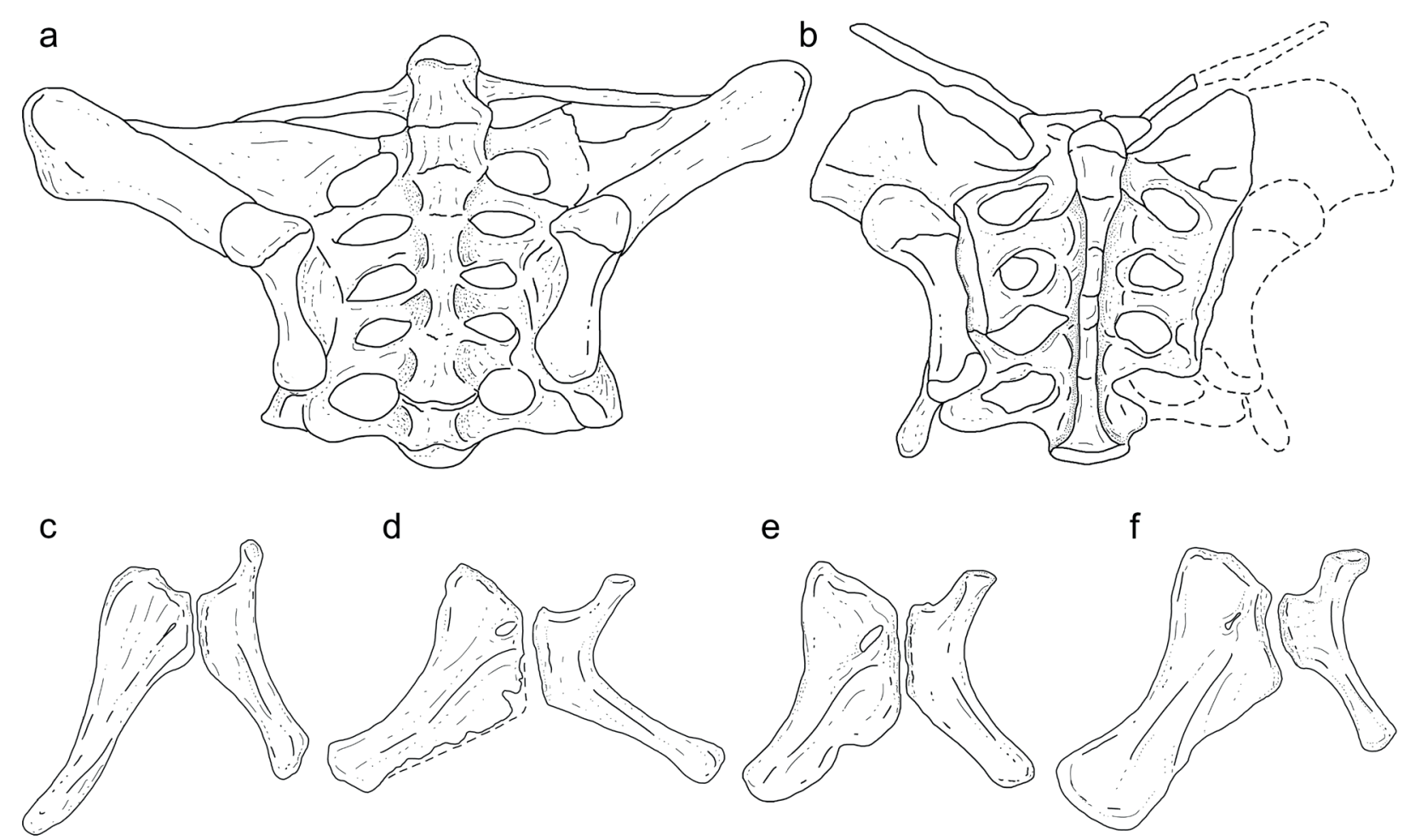

Figure 6 - Morphological comparison of pelvic elements of South American (Argentinean) titanosaurs. Ventral view of sacrum and ilia of (a) Neuquensaurus australis, MCS 5/16, redrawn from Salgado et al. (2005) and (b) Overosaurus paradasorum, MAUPv-CO-439, redrawn from Coria et al. (2013). Lateral view of left pubis and ischium of (c) Dreadnoughtus schrani, MPM-PV 1156, redrawn from Ullmann and Lacovara (2016), (d) Muyelensaurus pecheni, MRS-Pv 88 (reversed), redrawn from Calvo et al. (2007c), (e) Andesaurus delgadoi, MUCPv-132, redrawn from Mannion and Calvo (2011), (f) Futalognkosaurus dukei, MUCPv-323 (reversed), redrawn from Calvo et al. (2007b). Not to scale.

(e.g., Dreadnoughtus, Ullmann and Lacovara 2016, Traukutitan, Juárez Valieri and Calvo 2011). Moreover, in the femora of many derived titanosaurs, the fibular condyle projects further distally than the tibial condyle (González Riga et al. 2018), and in saltasaurines, these condyles extend onto the anterior surface of the shaft (Wilson 2002, Ullmann and Lacovara 2016).

\section{TIBIA AND FIBULA}

Both the tibia and fibula are preserved in Aeolosaurus rionegrinus, Antarctosaurus wichmannianus, Bonatitan, Bonitasaura, Dreadnoughtus, Elaltitan, Epachthosaurus, Laplatasaurus (Gallina and Otero 2015), Mendozasaurus, Muyelensaurus, Neuquensaurus, Saltasaurus, and Uberabatitan; one or the other of these bones is known in a few other taxa as well (Table I, Figure 8a-1). Like other appendicular elements, the tibia and fibula of South American titanosaurs vary in proportions from relatively gracile to robust. Saltasaurines (Figure 8e) have very stout tibiae with a prominent cnemial crest, whereas in other taxa such as A. wichmannianus, Epachthosaurus (Figure 8c), and Mendozasaurus (Figure $8 \mathrm{a}$ ) the tibia is considerably slenderer and the crest is weakly developed; other forms such as Dreadnoughtus (Figure 8d), Futalognkosaurus (Calvo 2014), and Laplatasaurus (Figure 8b) exhibit an intermediate condition. The extent of the cnemial fossa on the proximal end of the tibia is also highly variable among South American titanosaurs (Gallina and Otero 2015). In lithostrotian titanosaurs, the mediolateral width 

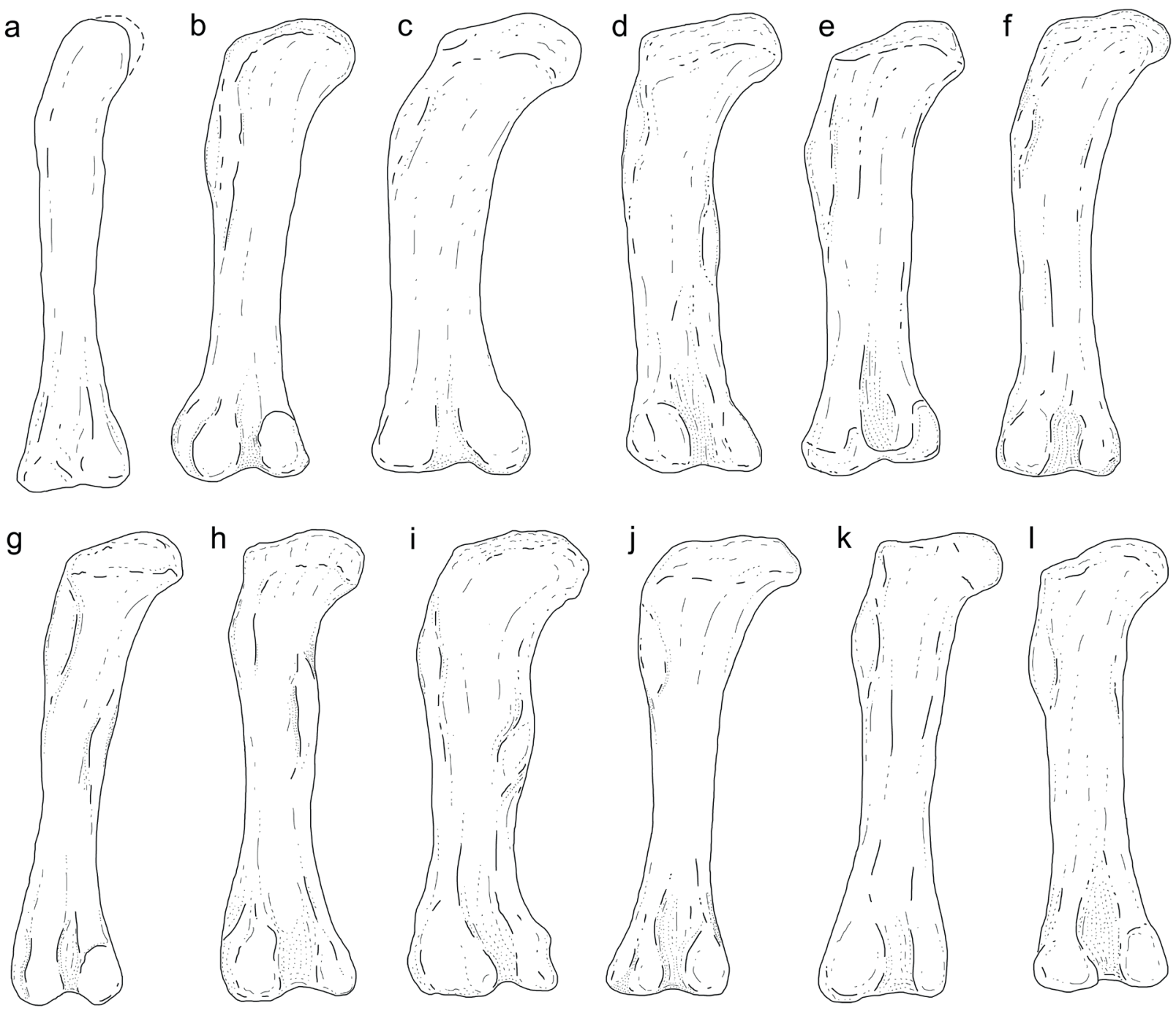

Figure 7 - Morphological comparison of South American titanosaur femora. (a) Right femur in anterior view of Atacamatitan chilensis, SGO-PV-961g, redrawn from Kellner et al. (2011), (b) left femur in posterior view of Neuquensaurus australis, MLPCS 1118, redrawn from Otero (2010), (c) right femur in anterior view of 'Neuquensaurus robustus,' MCS-9, redrawn from Otero (2010), (d) right femur in posterior view (reversed) of Epachthosaurus sciuttoi, UNPSJB-PV 920, redrawn from Martínez et al. (2004), (e) right femur in posterior view of Saltasaurus loricatus, PVL 4017-79, redrawn from Powell (1992), (f) left femur in posterior view of Petrobrasaurus puestohernandezi, MAU-PV-PH 449/8, redrawn from Filippi et al. (2011b), (g) left femur in posterior view of Mendozasaurus neguyelap, IANIGLA-PV 073/4, redrawn from González Riga et al. (2018), (h) right femur in posterior view (reversed) of Patagotitan mayorum, MPEF-PV 4400/26, redrawn from Carballido et al. (2017), (i) left femur in posterior view of Dreadnoughtus schrani, MPM-PV 1156, redrawn from Ullmann and Lacovara (2016), (j) right femur in posterior view (reversed) of 'Antarctosaurus' giganteus, drawn from unpublished photo by L.D.O.D., (k) left femur in posterior view of Bonatitan reigi, MACN-PV RN 821, redrawn from Salgado et al. (2015), (j) left femur in anterior view (reversed) of Traukutitan eocaudata, MUCPv-204, redrawn from Juárez Valieri and Calvo (2011). Not to scale.

of the distal end of the tibia is at least twice the diameter of the bone at midshaft (Wilson 2002, Mannion et al. 2013).

The fibulae of South American titanosaurs exhibit variability in aspects such as the anteroposterior width of the proximal end, the robusticity and straightness of the shaft, and the development, location, and morphology of the lateral trochanter. The proximal end is anteroposteriorly broad in taxa such as Dreadnoughtus (Figure 
81) and Uberabatitan (Figure 8g) but much narrower in many others (e.g., Epachthosaurus, Laplatasaurus, Mendozasaurus, Figure 8f, h, j). Similarly, the shaft is relatively robust in Dreadnoughtus, Uberabatitan, and saltasaurines (e.g., Figure 8k) but more gracile in Laplatasaurus and Mendozasaurus. Interestingly, despite the undoubtedly gigantic size of the animal, the fibula of Argentinosaurus (initially described as a tibia, Bonaparte and Coria 1993) is considerably more gracile and slender-shafted than the stouter fibulae of taxa such as A. rionegrinus, Dreadnoughtus, Elaltitan, Laplatasaurus, Uberabatitan, and saltasaurines. Nevertheless, at a colossal $1.55 \mathrm{~m}$ in length, the Argentinosaurus fibula remains the longest yet known for a titanosaur by a considerable margin (see Lacovara et al. 2014, table 1). When observed in lateral view, the fibular shaft is slightly sigmoid in Dreadnoughtus, Epachthosaurus, and Saltasaurus (Powell 1992) but generally straighter in forms such as Argentinosaurus, Laplatasaurus, Mendozasaurus, and Neuquensaurus. The lateral trochanter is very well-developed in taxa such as Dreadnoughtus, Laplatasaurus, Neuquensaurus, and Uberabatitan but less so in others (e.g., Epachthosaurus, Mendozasaurus). It is placed slightly proximal to midshaft in most South American titanosaurs but more distally in selected taxa from other landmasses (e.g., the Madagascan titanosaur Rapetosaurus, Figure 8i). The lateral trochanter takes the form of a single tuberosity in most taxa (e.g., Dreadnoughtus, Laplatasaurus) but is comprised of two subparallel ridges in Epachthosaurus (Martínez et al. 2004). In Laplatasaurus, Uberabatitan, and perhaps a few other titanosaurs there is a marked concavity immediately posterior to the lateral trochanter (Salgado and de Souza Carvalho 2008, Gallina and Otero 2015).

\section{TARSUS AND PES}

The tarsus of titanosaurs is represented exclusively by the astragalus, with the possible exception of Elaltitan for which an ossified calcaneum has been reported (Mannion and Otero 2012); a calcaneum was also described for Neuquensaurus by Huene (1929) but this bone is now lost (Otero 2010). Among South American titanosaurs, the astragalus is known in only 11 taxa: Aeolosaurus rionegrinus, Bonatitan, Bonitasaura, Dreadnoughtus, Elaltitan, Epachthosaurus, Mendozasaurus, Muyelensaurus, Neuquensaurus, Notocolossus, and Uberabatitan (Table I, Figure $8 \mathrm{~m}$-p). In several of these forms (e.g., Notocolossus, Uberabatitan, Figure 8n, p) it is proximodistally tall and pyramidal in shape, but in others (e.g., Dreadnoughtus [Figure 8m], Elaltitan [Figure 8o], Epachthosaurus, Mendozasaurus) it is lower. D'Emic (2012) regarded a mediolaterally narrow astragalus as a synapomorphy of Saltasauridae. The element identified as the calcaneum of Elaltitan is amorphous and globular, consistent in appearance with the calcanea of nontitanosaurian sauropods (Figure 8q, Mannion and Otero 2012).

Complete pedes are extremely scarce in the fossil record of titanosaurs (Table I, Figure 9, see also Curry Rogers 2005, González Riga 2011), and indeed, sauropods as a whole (McIntosh 1990). Intrinsic factors related to the large body dimensions of these dinosaurs coupled with the relatively small size and fragility of their skull bones, posterior caudal vertebrae, and manual and pedal elements evidently led to the early disarticulation, and therefore loss, of these comparatively diminutive bones during the biostratinomic stage of necrokinesis (González Riga et al. 2008b). In fact, of the well over 70 valid titanosaurian taxa recognized at present (Wilson et al. 2016, M.C.L. pers. obs.), only three are known from complete and articulated pedes: Opisthocoelicaudia from Mongolia (Figure 9a, ZPAL MgD-I/48, Borsuk- 
a

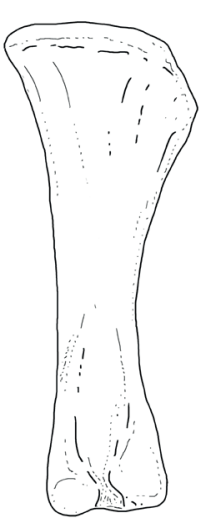

b

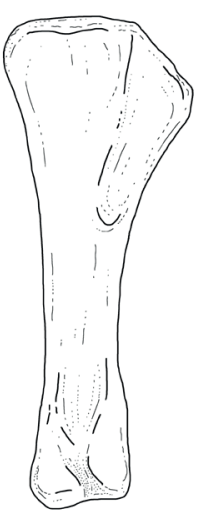

f

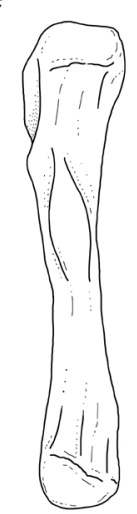

$\mathrm{g}$

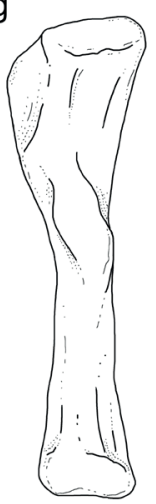

h

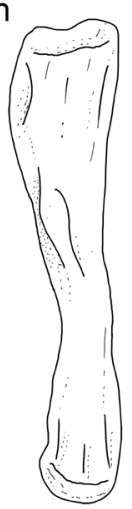

c

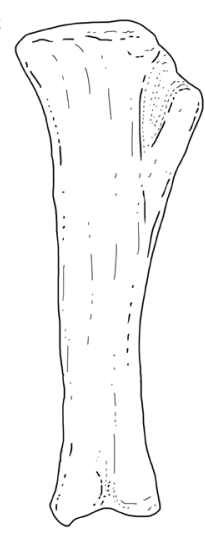

i

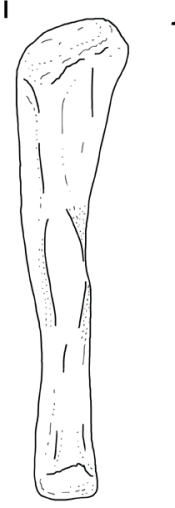

d

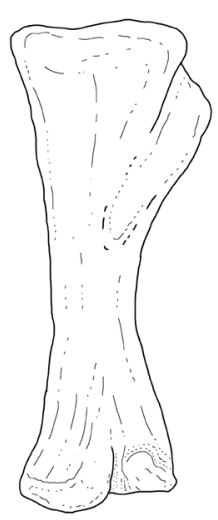

$\mathrm{k}$

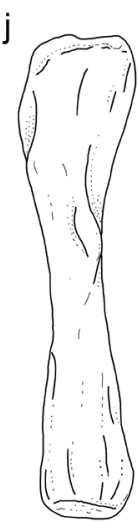

e
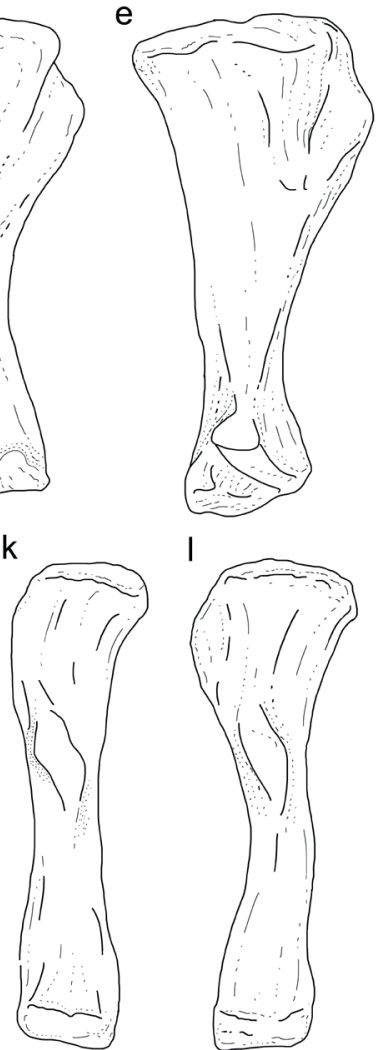

0
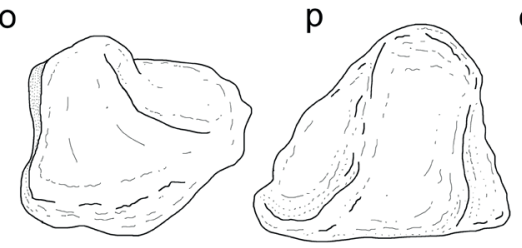

q
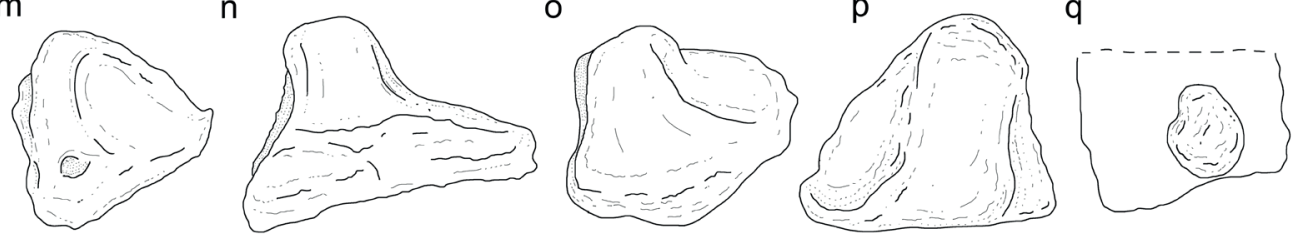

Figure 8 - Morphological comparison of titanosaurian tibiae (a-e), fibulae (f-l), and tarsals (m-q). South American taxa denoted with an asterisk. (a)-(e), right tibiae in lateral view: (a) Mendozasaurus neguyelap*, IANIGLA-PV 073/2, redrawn from González Riga et al. (2018), (b) Laplatasaurus araukanicus*, MLP-CS 1128, redrawn from Gallina and Otero (2015), (c) Epachthosaurus sciuttoi*, UNPSJB-PV 920, redrawn from Martínez et al. (2004), (d) Dreadnoughtus schrani*, MPM-PV 1156, redrawn from Ullmann and Lacovara (2016), (e) Saltasaurus loricatus*, PVL 4017-84, redrawn from Powell (1992). (f)-(l), left fibulae in lateral view: (f) Laplatasaurus araukanicus* (reversed), MLP-CS 1127, redrawn from Gallina and Otero (2015), (g) Uberabatitan ribeiroi*, CPP-1107-UrHo, redrawn from Salgado and de Souza Carvalho (2008), (h) Epachthosaurus sciuttoi*, UNPSJB-PV 920, redrawn from Martínez et al. (2004), (i) Rapetosaurus krausei (reversed), FMNH PR 2209, redrawn from Curry Rogers (2009), (j) Mendozasaurus neguyelap*, IANIGLA-PV 074/3, redrawn from González Riga (2003), (k) 'Neuquensaurus robustus'*, MLP-CS 1265, redrawn from Otero (2010), (I) Dreadnoughtus schrani*, MPM-PV 1156, redrawn from Ullmann and Lacovara (2016). (m)-(q), tarsal elements in various views: (m) left astragalus in proximal view of Dreadnoughtus schrani*, MPM-PV 1156, redrawn from Ullmann and Lacovara (2016), (n) right astragalus in anterior view of Notocolossus gonzalezparejasi*, UNCUYO-LD 302, redrawn from González Riga et al. (2016), (o) right astragalus in anterior view of Elaltitan lilloi*, PVL 4628, redrawn from Mannion and Otero (2012), (p) left astragalus in anterior view of Uberabatitan ribeiroi*, CPP-1082-UrHo, redrawn from Salgado and de Souza Carvalho (2008), (q) calcaneum adhered to medial surface of distal fibula of Elaltitan lilloi*, PVL 4628, redrawn from Mannion and Otero (2012). Not to scale. 
Bialynicka 1977) and Epachthosaurus (Figure 9b, UNPSJB-PV 920, Martínez et al. 2004) and Notocolossus (Figure 9g, UNCUYO-LD 302, González Riga et al. 2016) from Argentina. Two additional titanosaurs with complete, articulated hind feet may be added to this select group: the Agua de Padrillo taxon (UNCUYO-LD 313, González Riga et al. 2015), which preserves both complete pedes and is currently undergoing laboratory preparation, and the La Invernada taxon (MUCPv-1533, González Riga et al. 2008a), which preserves the complete left fore- and hind limbs and is presently under study (Figures 1a, b, 9c, d). Preliminary analyses suggest that both the Invernada and Padrillo forms correspond to new genera (B.J.G.R. pers. obs.). Pedal elements are known for many other titanosaurs, including other South American taxa (see Table I), but none of these preserve the pes completely and in articulation (though a few other specimens approach this condition, e.g., ?Alamosaurus NMMNH P-49967, Figure 9e, D'Emic et al. 2011).

In sauropods, a progressive reduction in both the number and length of the pedal phalanges has been previously documented and is the most apparent evolutionary trend in the structure of the hind foot in these herbivorous dinosaurs (Bonnan 2005, González Riga et al. 2008a, 2016). For example, in the basal eusauropods Shunosaurus (Zhang 1988) and Omeisaurus (He et al. 1988), a total of 12 pedal phalanges are described. Titanosaurs, by contrast, have fewer pedal phalanges. The possible basal titanosaur Epachthosaurus has a pedal phalangeal formula of 2-2-3-2-0 (nine phalanges total, Martínez et al. 2004), and an even more reduced formula of 2-2-2-2-0 (eight phalanges total) occurs in the Padrillo (UNCUYO-LD 313) and Invernada (MUCPv-1533) taxa, Notocolossus (González Riga et al. 2016), and Mendozasaurus (González Riga et al. 2018). Opisthocoelicaudia was originally described as having a pedal phalangeal formula of 2-2-2-1-0 (Borsuk-Bialynicka 1977), but the shape of the distal condyle of the first phalanx of digit IV suggests the presence of a second ossified phalanx in this digit. Because of this, we herein interpret that this taxon had a phalangeal formula of 2-2-2$2-0$, as is the case in all other derived titanosaurs for which the pes is completely represented.

Another relevant aspect of sauropod pedal structure is the development of the distal articular facets of the metatarsals. Indiplodocids, for example, the articular facets are strongly convex and extend onto the dorsal (= anterior) face of the metatarsals (Bonnan 2005). This condition is clearly visible in Barosaurus (AMNH 6341, B.J.G.R. pers. obs.), in which the distal end of metatarsal I is strongly convex, indicating a wide range of mobility of phalanx I-1. A similar but less pronounced case is observed in Apatosaurus (CM 3018, phalangeal formula 2-3-3-2-1, B.J.G.R. pers. obs.), suggesting that the elevated mass of this taxon may have led to a reduction in the mobility of its phalanges in comparison with the more lightly-built diplodocine diplodocids Barosaurus and Diplodocus. In the macronarian Camarasaurus, two distal articular facets are present in metatarsals I and II (YPM 1901, B.J.G.R. pers. obs.), in accordance with the well-developed pedal phalanges of this taxon (phalangeal formula 2-3-2-2-1, McIntosh et al. 1996).

In titanosaurs, by contrast, the distal articular facets of the metatarsals are less developed than in other sauropods. In Mendozasaurus, for instance, these facets are only slightly convex and only some of them extend onto the dorsal surface of the metatarsal in question (González Riga et al. 2018). An extreme case is observed in Notocolossus, the metatarsals of which have nearly flat distal articular facets, indicating reduced mobility of the digits (González Riga et al. 2016, B.J.G.R. pers. obs.). Interestingly, unlike other titanosaurs, the pedal unguals of this gigantic taxon are small, blunt, and amorphous; although there is some possibility that this condition is pathologic (González Riga 
et al. 2016), it is also consistent with the limited development of the distal articular facets of the metatarsals.

A distinctive character of some titanosauriform pedal unguals is the presence of an elongate tuberosity on the ventral (= plantar) surface. Among South American titanosaurs this structure is present in Bonatitan (Salgado et al. 2015), Brasilotitan (Machado et al. 2013), Dreadnoughtus (Ullmann and Lacovara 2016), Mendozasaurus (González Riga et al. 2018), the La Invernada taxon (González Riga et al. 2008a), and probably others.

González Riga et al. (2016) preliminarily recognized two primary titanosaurian pedal skeletal morphotypes, which they termed 'longfooted' (where, as in non-titanosaurian sauropods, the first four metatarsals exhibit a significant increase in length and a decrease in robusticity from medial to lateral) and 'short-footed' (with metatarsals that are all roughly the same length). Further study has led us to recognize considerable variation within González Riga et al.'s (2016) longfooted morphotype, revealing a broad diversity in form (Figure 9). Moreover, within Titanosauria, there is no clear correlation between body size and pedal osteology; instead, the differing hind foot architecture of various titanosaurs is probably more intimately related to evolutionary trends seen within different lineages.

The short-footed pedal morphotype is a massive structure that has thus far been observed only in Notocolossus (Figure 9g). This giant sauropod exhibits the lowest differences between the lengths of the metatarsals of any titanosaurian taxon yet discovered (for instance, the ratio of the length of metatarsal III to that of metatarsal I is only 1.14, González Riga et al. 2016). Moreover, in Notocolossus, differences in robusticity between metatarsal I and metatarsals II-V are less pronounced than in other titanosaurs. This may be quantified using the Metatarsal Robustness Index (MtRI), which is herein defined as the minimum mediolateral breadth of metatarsals II-V divided by that of metatarsal I. In Notocolossus, the MtRI is greater than 0.70 in metatarsals II-V. Moreover, the non-ungual phalanges are relatively long and wide in relation to the metatarsals, and both the size and shape of the unguals are unique, as noted above and as was described by González Riga et al. (2016).

As mentioned above, several variances may be observed within the long-footed titanosaurian morphotype (Figure 9a-f). The medium-sized derived titanosaur Opisthocoelicaudia (body length $\sim 12 \mathrm{~m}$, femoral length $1.39 \mathrm{~m}$, Borsuk-Bialynicka 1977) has a relatively short, compact metatarsus, very short non-ungual phalanges, and large unguals (Figure 9a). Metatarsal V is shorter than metatarsal I (metatarsal V length/metatarsal I length $=0.93$, Borsuk-Bialynicka 1977). Metatarsal III is the longest, in contrast to other titanosaurs (metatarsal III length/metatarsal I length $=1.33$, González Riga et al. 2016) (Table II).

The other long-footed titanosaurs analyzed herein are Epachthosaurus (Figure 9b, Martínez et al. 2004), Mendozasaurus (Figure 9f, González Riga et al. 2018), the unnamed Invernada and Padrillo taxa (Figure 9c, d, González Riga et al. 2008a, 2015), and NMMNH P-49967, an isolated pes provisionally attributed to Alamosaurus (Figure 9e, D'Emic et al. 2011). In contrast to Opisthocoelicaudia, in all of these taxa, metatarsal $\mathrm{V}$ is longer than metatarsal I and metatarsals I-IV show a progressive increase in length; because of this, metatarsal IV is the longest (the length ratio of metatarsal IV/metatarsal I is $1.39-1.57$ in these taxa) (Table II). The unguals are relatively large in relation to metatarsal length. Of all titanosaurians for which the pes is completely known, Epachthosaurus is unique in retaining nine phalanges. This accords with the basal position of this genus that is frequently recovered by phylogenetic analyses (e.g., Carballido et al. 2017) and the hypothesis of progressive reduction of the 
a

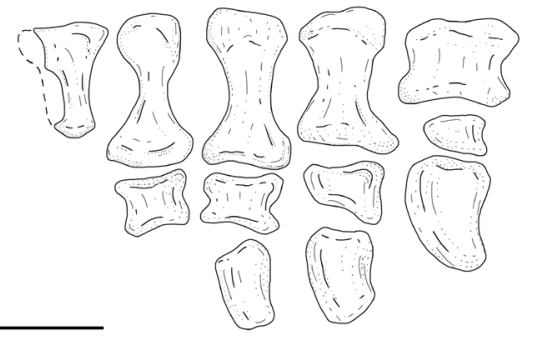

C

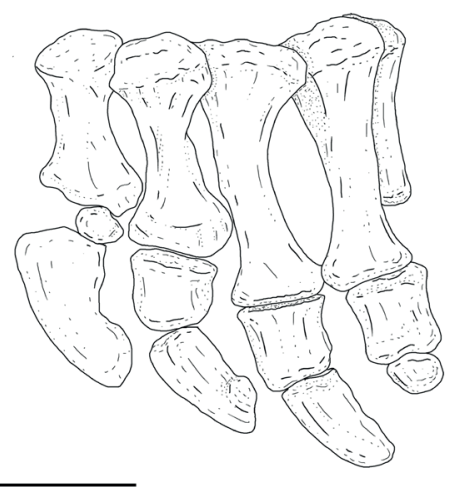

e

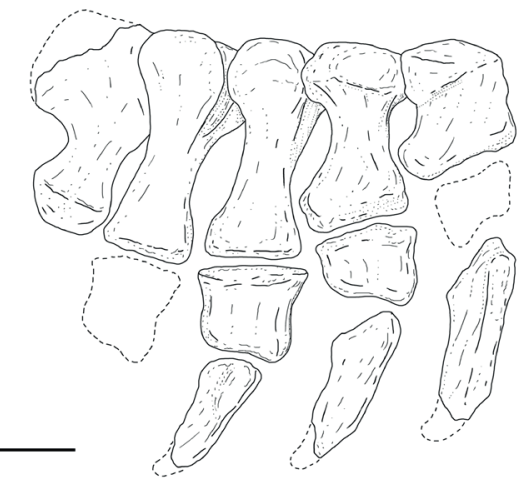

b

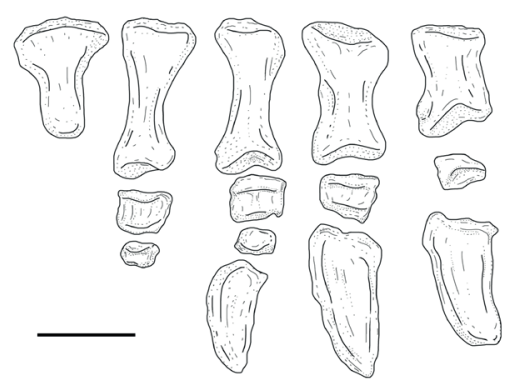

d

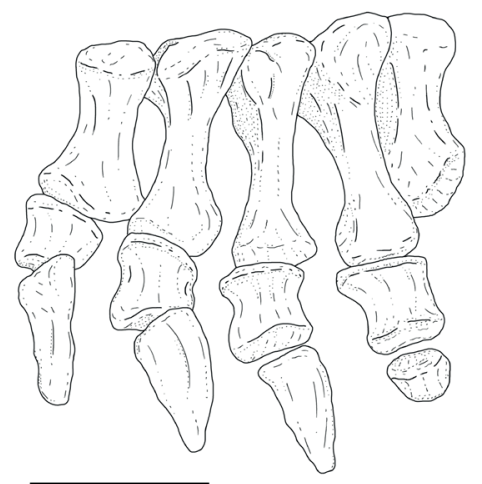

f

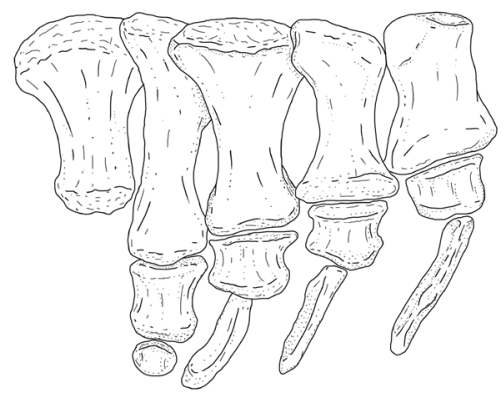

g

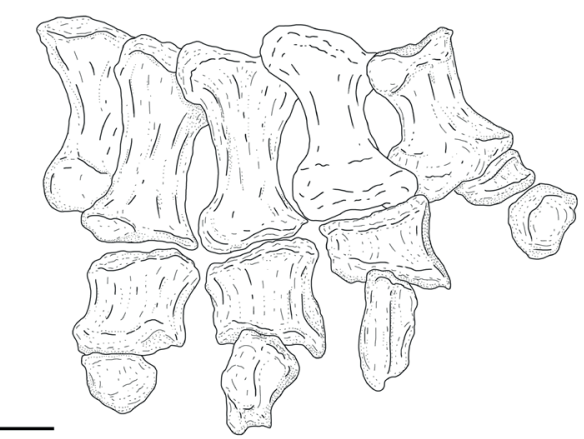

Figure 9 - The best-preserved pedes of titanosaurian sauropods. South American (Argentinean) taxa marked with an asterisk. (a) Opisthocoelicaudia skarzynskii, ZPAL MgD-I/48, right pes, redrawn from Borsuk-Bialynicka (1977), (b) Epachthosaurus sciuttoi*, UNPSJB-PV 920, right pes, redrawn from Martínez et al. (2004), (c) La Invernada taxon*, MUCPv-1533, left pes, redrawn from González Riga et al. (2008a), (d) Agua del Padrillo taxon*, UNCUYO-LD 313, left pes, redrawn from González Riga et al. (2015), (e) ?Alamosaurus sanjuanensis, NMMNH P-49967, right pes, redrawn from D’Emic et al. (2011), (f) Mendozasaurus neguyelap*, IANIGLA-PV 077/1-10, 078/1-2, 079, right pes, redrawn from González Riga et al. (2018), (G) Notocolossus gonzalezparejasi*, UNCUYO-LD 302, right pes, redrawn from González Riga et al. (2016). Scale bars equal $10 \mathrm{~cm}$. 
TABLE II

Proximodistal lengths and relative proportions of metatarsals of titanosaurian sauropods with the most completely preserved pedes. Roman numerals indicate metatarsal number. Columns I-V indicate lengths in mm; remaining columns are length ratios of various metatarsals.

\begin{tabular}{|c|c|c|c|c|c|c|c|c|c|c|c|}
\hline Taxon & Specimen & I & II & III & IV & $\mathbf{V}$ & II / I & III / I & IV / I & V / I & Source \\
\hline $\begin{array}{c}\text { Opisthocoelicaudia } \\
\text { skarzynskii }\end{array}$ & ZPAL MgD-I/48 & 150 & 180 & 200 & 180 & 140 & 1.20 & 1.33 & 1.20 & 0.93 & $\begin{array}{c}\text { Borsuk- } \\
\text { Bialynicka (1977) }\end{array}$ \\
\hline $\begin{array}{c}\text { Epachthosaurus } \\
\text { sciuttoi }\end{array}$ & UNPSJB-PV 920 & 125 & 153 & 177 & 185 & 153 & 1.22 & 1.41 & 1.48 & 1.22 & $\begin{array}{l}\text { Martínez et al. } \\
\text { (2004) }\end{array}$ \\
\hline Padrillo taxon & UNCUYO-LD 313 & 109 & 138 & 146 & 152 & 130 & 1.26 & 1.33 & 1.39 & 1.19 & $\begin{array}{c}\text { González Riga et } \\
\text { al. (2016) }\end{array}$ \\
\hline Invernada taxon & MUCPv-1533 & 120 & 137 & 168 & 172 & 127 & 1.14 & 1.40 & 1.43 & 1.05 & $\begin{array}{c}\text { González Riga et } \\
\text { al. (2008) }\end{array}$ \\
\hline $\begin{array}{l}\text { ?Alamosaurus } \\
\text { sanjuanensis }\end{array}$ & NMMNH P-49967 & 195 & 245 & 270 & 291 & 281 & 1.25 & 1.38 & 1.49 & 1.44 & $\begin{array}{l}\text { D'Emic et al. } \\
\text { (2011) }\end{array}$ \\
\hline $\begin{array}{l}\text { Mendozasaurus } \\
\text { neguyelap }\end{array}$ & IANIGLA-PV 077 & 135 & 158 & 181 & 212 & 169 & 1.17 & 1.34 & 1.57 & 1.25 & $\begin{array}{c}\text { González Riga et } \\
\text { al. (2018) }\end{array}$ \\
\hline $\begin{array}{c}\text { Notocolossus } \\
\text { gonzalezparejasi }\end{array}$ & UNCUYO-LD 302 & 164 & 185 & 187 & 218 & 196 & 1.12 & 1.14 & 1.32 & 1.19 & $\begin{array}{c}\text { González Riga et } \\
\text { al. (2016) }\end{array}$ \\
\hline
\end{tabular}

pedal phalanges within Titanosauria (González Riga et al. 2008a, 2016).

Among this second group of long-footed titanosaurs, thereare, asyet, nodefinitivecorrelations between pedal structure and body size, though some possible trends are evident. In the smallerbodied taxa within this group (Epachthosaurus and the Invernada and Padrillo taxa, with body lengths of up to approximately $10 \mathrm{~m}$, Martínez et al. 2004, González Riga et al. 2008a), metatarsals IV and $\mathrm{V}$ are relatively slender (Figure 9b-d). In contrast, in ?Alamosaurus (NMMNH P-49967) and Mendozasaurus, metatarsal V is relatively robust and longer than metatarsals I and II (Figure $9 \mathrm{e}, \mathrm{f})$. Both of these latter animals were very large: in ?Alamosaurus, metatarsal IV is $29.1 \mathrm{~cm}$ in length, and the femoral length of this individual has been estimated at 1.6-2.0 m (D'Emic et al. 2011, González Riga et al. 2016). Similarly, metatarsal III of an undescribed specimen of Mendozasaurus (UNCUYO-LD 356) is $29.2 \mathrm{~cm}$ in length, and as such, the individual in question was probably comparable in size to that represented by NMMNH P-49967. Further discoveries of relatively complete titanosaurian pedes are needed to further evaluate the potential relationships between body size and pedal morphology discussed herein.

\section{DISCUSSION}

The skeletal structure of sauropods has traditionally been interpreted as being relatively conservative in comparison to that of other dinosaurs. This is documented in, for example, Wilson and Curry Rogers' (2005) summary of the history of sauropod discoveries. In an early stage of the study of these iconic herbivorous dinosaurs, Romer (1968) lamented the difficulty in achieving a classification of sauropods due to their relatively incomplete fossil record. Thankfully, however, the sauropod record has improved dramatically in recent decades, leading to significant advances in knowledge of the anatomy, evolution, and paleobiology of these animals. As Wilson and Curry Rogers (2005) pointed out, "The improvement in our understanding of sauropod phylogeny is the result of an improved sauropod fossil record."

Many sauropod species are primarily defined on anatomical characters derived from the presacral, sacral, and/or anterior caudal vertebrae, and therefore, many authors have justifiably 
focused much of their attention on the axial skeleton (e.g., Bonaparte 1999, Wilson 1999, 2012). Knowledge of other regions of the sauropod skeleton, especially the skull, manus, and pes, has lagged behind understanding of vertebral anatomy, and as such, the extent of morphological variability in these parts of the skeleton has not been as thoroughly characterized. Nevertheless, there is no definitive evidence that certain structures changed significantly more than others through sauropod evolutionary history. As more discoveries have been made, it has become apparent that some parts of the sauropod skeleton deserve more attention from researchers than they had previously been afforded. This is certainly the case as regards the appendicular skeleton of titanosaurs.

At first glance, the appendicular anatomy of titanosaurs may appear fairly homogeneous. However, as more well-preserved specimens have come to light, it has become clear that there is considerable variation in the size and morphology of the girdle and limb elements within the clade. Accordingly, a significant number of appendicular skeletal characters have been incorporated into recent phylogenetic analyses of Titanosauria and more inclusive clades such as Titanosauriformes, Macronaria, and Neosauropoda (e.g., Curry Rogers 2005, D’Emic 2012, Mannion et al. 2013, González Riga et al. 2016, 2018, Gorscak and O'Connor 2016, Carballido et al. 2017, Sallam et al. 2018). Although the percentages of appendicular skeletal characters in these analyses have varied considerably, the absolute number of characters has generally increased over the years. For example, in a study of the evolutionary history of Titanosauriformes, D'Emic (2012) included 51 appendicular characters out of a total of $119(42 \%)$, whereas in their analysis of the relationships of Notocolossus, González Riga et al. (2016) modified the dataset of Carballido and Sander (2014) to include 119 appendicular features, comprising 34\% of the total.
COMMENTS ON APPENDICULAR SYNAPOMORPHIES OF SELECTED TITANOSAURIAN CLADES

Here, we follow the node-based phylogenetic definition of Titanosauria proposed by Salgado et al. (1997) and subsequently modified by Wilson and Upchurch (2003). Many titanosaurian clades exhibit considerable diversity. One of these appears to be Lognkosauria, which is defined as the most recent common ancestor of Mendozasaurus neguyelap and Futalognkosaurus dukei and all descendants (Calvo et al. 2007a). Whereas prior studies (e.g., González Riga and Ortiz David 2014, González Riga et al. 2016) restricted Lognkosauria to these two species, more recent analyses by Carballido et al. (2017) and González Riga et al. (2018) have suggested a more diverse clade that also includes Argentinosaurus, Patagotitan, and possibly Drusilasaura, Notocolossus, Puertasaurus, and/or Quetecsaurus.

In previous phylogenetic analyses, Titanosauria has been diagnosed by various appendicular synapomorphies, some of which were initially proposed for the titanosaurian subclades Titanosauroidea or Titanosauridae (which have since been abandoned due to the invalid status of the genus Titanosaurus, Wilson and Upchurch 2003). A review of existing phylogenetic analyses of Titanosauria demonstrates that the clade has not always been supported by the same suite of appendicular skeletal characters; in other words, there is no universal agreement among researchers as to which morphologies of the girdles and limbs are diagnostic of Titanosauria. In recent years, phylogenetic studies have included additional taxa and characters, and as a result, some previouslyproposed titanosaurian synapomorphies are now thought to characterize either more inclusive or less inclusive clades. The appendicular skeletal character states that were proposed as synapomorphies of Titanosauria and several of its subclades in the 
analyses of D'Emic (2012), Mannion et al. (2013), and González Riga et al. (2016) are summarized in Table III. Other recent, comprehensive phylogenetic analyses of titanosaurs include, among others, those of Gorscak and O'Connor (2016), Poropat et al. (2016), Carballido et al. (2017), Gorscak et al. (2017), González Riga et al. (2018), and Sallam et al. (2018).

\section{Titanosauria}

The clade Titanosauria has historically been supported primarily by vertebral characters, with appendicular synapomorphies playing a secondary role. For example, Salgado et al. (1997) postulated only one appendicular synapomorphy for Titanosauria: the presence of a pubis that is considerably longer than the ischium (Salgado et al. 1997:character 24). This feature is unknown in some titanosaurs and therefore has an ambiguous distribution, as seen, for example, in the dataset of Salgado et al. (2015).

Wilson (2002), in an extensive study of sauropod phylogeny, proposed four appendicular synapomorphies of Titanosauria: crescentic sternal plates (his character 158), prominent ulnar olecranon process (reversal) (character 168), ischial blade plate-like, no emargination distal to pubic peduncle (character 193), and distal tibia expanded mediolaterally to twice midshaft breadth (character 205). Subsequently, D’Emic (2012), in a large-scale analysis of Titanosauriformes, recovered only a single appendicular synapomorphy of Titanosauria, character 193 of Wilson's (2002) matrix, referring to the morphology of the ischial blade. In D'Emic's (2012) analysis, a pubis considerably longer than the ischium (the lone appendicular synapomorphy of Titanosauria according to Salgado et al. 1997, their character 24) is regarded as diagnostic of a more inclusive clade that includes Sauroposeidon + (Tastavinsaurus + (Euhelopodidae + (Chubutisaurus + Titanosauria))) (D’Emic 2012: character 102).
In the phylogenetic analysis of Carballido et al. (2011), Titanosauria was supported by one unambiguous appendicular synapomorphy: the absence of a strongly developed ventromedial process on the scapula (character 202, state 0). According to Carballido et al. (2011), this feature is present only in titanosaurian outgroups (e.g., Chubutisaurus, Ligabuesaurus, Wintonotitan).

In the phylogenetic study of González Riga and Ortiz David (2014), Titanosauria was supported by two unambiguous appendicular synapomorphies: absence of well-developed distal phalangeal articular facets on metacarpals (character 71, state 1), and humerus/femur length ratio less than 0.9 (character 77 , state 1 ). Both of these traits are absent in the non-titanosaurian titanosauriform Ligabuesaurus (Bonaparte et al. 2006). In their revision of another non-titanosaurian titanosauriform, Chubutisaurus, Carballido et al. (2011:104) estimated a humerus/femur ratio of 0.86 for this taxon, proposing that a value of less than 0.8 was characteristic of titanosaurs.

The absence of ossified manual phalanges was proposed as a synapomorphy of Opisthocoelicaudiinae by Wilson (2002:character 181, state 2), although Opisthocoelicaudia possesses at least one vestigial phalanx on manual digit IV (Borsuk-Bialynicka 1977:31). Previously, Salgado et al. (1997) had proposed this morphology as diagnostic of their 'Titanosauridae' (a clade that is largely similar to what is now known as Lithostrotia). Salgado et al. (1997) indicated that the absence of manual phalanges should be evaluated based on the morphology of the distal articular facets of the metacarpals, due to the likelihood that such phalanges could easily be lost due to the taphonomic process of necrokinesis. Similarly, Giménez (1992) proposed to examine the distal ends of metacarpals to assess the presence of manual phalanges, since in several derived titanosaurs the metacarpals exhibit roughened, flattened distal surfaces rather than convex articular 
TABLE III

Proposed synapomorphies of the appendicular skeleton within Titanosauria and some of its subclades according to selected recent works (D'Emic 2012, Mannion et al. 2013, González Riga et al. 2016). Synapomorphies are ordered by anatomical region. (*) Description of synapomorphy modified from original source; (\#) synapomorphy obtained from a published phylogenetic analysis but not explicitly mentioned previously.

\begin{tabular}{|c|c|c|c|}
\hline Proposed synapomorphy & Diagnostic of & Source & $\begin{array}{c}\text { Character originally } \\
\text { proposed by }\end{array}$ \\
\hline $\begin{array}{l}\text { Scapulocoracoid suture flush, no } \\
\text { embayment at suture }\end{array}$ & Saltasauridae & D’Emic 2012 & Upchurch 1995, 1998 \\
\hline $\begin{array}{l}\text { Scapula, ventral margin with well- } \\
\text { developed ventromedial process (\#) }\end{array}$ & Titanosauria & $\begin{array}{l}\text { González Riga } \\
\text { et al. } 2016\end{array}$ & Carballido et al. 2011 \\
\hline $\begin{array}{l}\text { Coracoid anteroventral margin square } \\
\qquad(*)\end{array}$ & Saltasauridae & D’Emic 2012 & $\begin{array}{l}\text { Salgado et al. 1997, } \\
\text { Upchurch 1998, Sanz et } \\
\text { al. 1999, Wilson } 2002\end{array}$ \\
\hline Coracoid proximodistally long* & Lithostrotia & D’Emic 2012 & Wilson 2002 \\
\hline $\begin{array}{c}\text { Sternal plate length } \geq 65-70 \% \text { humerus } \\
\text { length }(*)\end{array}$ & Lithostrotia & $\begin{array}{l}\text { D’Emic 2012; } \\
\text { Mannion et al. } \\
2013\end{array}$ & $\begin{array}{l}\text { McIntosh 1990; } \\
\text { Upchurch } 1998\end{array}$ \\
\hline $\begin{array}{l}\text { Prominent posterolateral expansion of } \\
\text { sternal plate produces 'kidney-shaped' }\end{array}$ & Lithostrotia & $\begin{array}{l}\text { Mannion et al. } \\
2013\end{array}$ & $\begin{array}{c}\text { McIntosh 1990, Salgado } \\
\text { et al. 1997, Upchurch }\end{array}$ \\
\hline profile in dorsal view $(*)$ & & & 1998 \\
\hline $\begin{array}{l}\text { Humerus length less than } 80 \% \text { femur } \\
\text { length }(*)\end{array}$ & Saltasauridae & D’Emic 2012 & Wilson 2002 \\
\hline $\begin{array}{c}\text { Humeral deltopectoral crest extends } \\
\text { medially across anterior face of } \\
\text { humerus }(*)\end{array}$ & Titanosauria & $\begin{array}{l}\text { Mannion et al. } \\
2013\end{array}$ & $\begin{array}{l}\text { Sanz et al. 1999, Wilson } \\
\text { 2002, Upchurch et al. } \\
2004\end{array}$ \\
\hline $\begin{array}{l}\text { Humeral deltopectoral crest strongly } \\
\qquad \text { expanded distally }(*)\end{array}$ & Saltasauridae & D’Emic 2012 & Wilson 2002 \\
\hline $\begin{array}{c}\text { Humerus with strong posterolateral } \\
\text { bulge around level of deltopectoral } \\
\text { crest }\end{array}$ & Saltasauridae & D’Emic 2012 & D’Emic 2012 \\
\hline $\begin{array}{l}\text { Humeral radial and ulnar condyles } \\
\text { divided distally }(*)\end{array}$ & $\begin{array}{c}\text { Alamosaurus }+ \\
\text { 'Saltasaurini' }\end{array}$ & D’Emic 2012 & Wilson 2002 \\
\hline $\begin{array}{l}\text { Anterior surface of distal lateral } \\
\text { condyle of humerus undivided }\end{array}$ & Lithostrotia & $\begin{array}{l}\text { Mannion et al. } \\
2013\end{array}$ & D’Emic 2012 \\
\hline $\begin{array}{l}\text { Radius distal end beveled } \sim 20^{\circ} \\
\text { proximolaterally relative to shaft }\end{array}$ & Saltasauridae & D’Emic 2012 & Wilson 2002 \\
\hline $\begin{array}{c}\text { Prominent ulnar olecranon process, } \\
\text { projecting well above proximal } \\
\text { articulation }(*)\end{array}$ & Lithostrotia & $\begin{array}{l}\text { Mannion et al. } \\
2013\end{array}$ & $\begin{array}{l}\text { McIntosh 1990, Wilson } \\
\text { and Sereno } 1998\end{array}$ \\
\hline Carpus unossified or absent $(*)$ & Saltasauridae & D’Emic 2012 & $\begin{array}{c}\text { Upchurch 1998, Wilson } \\
2002\end{array}$ \\
\hline $\begin{array}{l}\text { Metacarpal I:metacarpal II/III } \\
\text { proximodistal length ratio } \geq 1.0\end{array}$ & Lithostrotia & $\begin{array}{l}\text { Mannion et al. } \\
2013\end{array}$ & Upchurch 1998 \\
\hline
\end{tabular}


TABLE III (continued)

\begin{tabular}{|c|c|c|c|}
\hline Proposed synapomorphy & Diagnostic of & Source & $\begin{array}{l}\text { Character originally } \\
\text { proposed by }\end{array}$ \\
\hline $\begin{array}{l}\text { Metacarpal V proximal end subequal } \\
\text { in size to that of metacarpal I }\end{array}$ & Saltasauridae & D’Emic 2012 & D'Emic 2012 \\
\hline $\begin{array}{l}\text { Ilium with kink on ventral margin of } \\
\text { preacetabular process }\end{array}$ & $\begin{array}{l}\text { Alamosaurus }+ \\
\text { 'Saltasaurini' }\end{array}$ & D’Emic 2012 & D’Emic 2012 \\
\hline $\begin{array}{l}\text { Anteroposterior to mediolateral width } \\
\text { ratio of iliac articular surface of pubis } \\
\qquad \geq 2.0\end{array}$ & Titanosauria & $\begin{array}{l}\text { Mannion et al. } \\
2013\end{array}$ & Mannion et al. 2013 \\
\hline $\begin{array}{l}\text { Acetabular margin of ischium strongly } \\
\text { concave in lateral view such that pubic }\end{array}$ & $\begin{array}{l}\text { Titanosauria } \\
\text { (Mannion et al. }\end{array}$ & $\begin{array}{l}\text { D’Emic 2012, } \\
\text { Mannion et al. }\end{array}$ & D’Emic 2012 \\
\hline $\begin{array}{l}\text { articular surface forms proximodorsal } \\
\text { projection }(*)\end{array}$ & $\begin{array}{c}\text { 2013) or } \\
\text { Lithostrotia } \\
\text { (D’Emic 2012) }\end{array}$ & 2013 & \\
\hline $\begin{array}{l}\text { No emargination of ischium distal to } \\
\text { pubic articulation }\end{array}$ & Titanosauria & $\begin{array}{l}\text { D’Emic 2012, } \\
\text { Mannion et al. } \\
2013\end{array}$ & $\begin{array}{l}\text { McIntosh 1990, } \\
\text { Upchurch 1998, Wilson } \\
2002\end{array}$ \\
\hline $\begin{array}{l}\text { Ratio of dorsoventral width of distal } \\
\text { end of ischial shaft:minimum shaft } \\
\text { dorsoventral width }<1.5\left(^{*}\right)\end{array}$ & Titanosauria & $\begin{array}{l}\text { Mannion et al. } \\
2013\end{array}$ & $\begin{array}{c}\text { McIntosh 1990, } \\
\text { Upchurch 1995, } 1998\end{array}$ \\
\hline $\begin{array}{l}\text { Femur with longitudinal ridge on } \\
\text { anterior face of shaft }\end{array}$ & $\begin{array}{l}\text { Alamosaurus }+ \\
\text { 'Saltasaurini' }\end{array}$ & D’Emic 2012 & Otero 2010 \\
\hline $\begin{array}{c}\text { Femoral distal condyles beveled } 10^{\circ} \\
\text { dorsomedially relative to shaft }\end{array}$ & Saltasauridae & D’Emic 2012 & Wilson 2002 \\
\hline $\begin{array}{l}\text { Ratio of mediolateral width of distal } \\
\text { end of tibia:long axis of a cross-section }\end{array}$ & Lithostrotia & $\begin{array}{l}\text { Mannion et al. } \\
2013\end{array}$ & Wilson 2002 \\
\hline \multicolumn{4}{|l|}{ horizontally through the midshaft $\geq 2.0$} \\
\hline $\begin{array}{l}\text { Laterally projected tibial cnemial crest } \\
\qquad(\#)\end{array}$ & Lithostrotia & $\begin{array}{l}\text { González Riga } \\
\text { et al. } 2016\end{array}$ & Wilson 2002 \\
\hline Astragalus mediolaterally narrow & Saltasauridae & D’Emic 2012 & D’Emic 2012 \\
\hline
\end{tabular}

facets. As was described by Apesteguía (2005), there seems to have been a progressive reduction of the manual phalanges from basal titanosauriforms to derived titanosaurs.

We observe at least two manual morphologies in titanosaurs that are pertinent to discussions of the presence or absence of ossified phalanges in these sauropods: (1) metacarpals with well-defined distal articular facets and curved metacarpal I, as evidence of manual phalanges, and (2) metacarpals with poorly-defined distal articular facets, with or without vestigial ossified manual phalanges. In the first case, the presence of manual phalanges is supported both by well-defined distal articular facets on the metacarpals and the discovery of manual phalanges associated with the specimens in question. This is the case for two early Late Cretaceous Australian taxa, Diamantinasaurus and Savannasaurus, described by Hocknull et al. (2009) and Poropat et al. (2015, 2016), respectively. In Diamantinasaurus, the manual elements were not preserved in articulation but have been tentatively 
interpreted as indicative of a manual phalangeal formula of 2-1-1-1-1. In Savannasaurus, Poropat et al. (2016) recognized at least two manual phalanges, though these authors did not specify to which digits these bones pertained. These important discoveries hint at the existence of diverse manual structures within Titanosauria, though articulated specimens are needed to confirm certain aspects of their anatomy (e.g., the proposed phalangeal formula of Diamantinasaurus). Additional titanosaurian taxa such as Andesaurus and Argyrosaurus exhibit indirect evidence of manual phalanges, though these bones have yet to be discovered in these taxa (Mannion and Calvo 2011, Mannion and Otero 2012). In these two large Patagonian titanosaurs, metacarpal I is curved and somewhat 'bananashaped,' similar to that of the basal titanosauriform Janenschia (Apesteguía 2005:334), thereby suggesting the possible presence of one or more diminutive manual phalanges (e.g., Figure 5c, Argyrosaurus).

In the second case, the metacarpals have poorly developed distal articular facets, and in two genera, Epachthosaurus and Opisthocoelicaudia, a rudimentary phalanx is present on digit IV. Though both of these taxa are represented by fully articulated postcranial skeletons, there is no evidence of other ossified manual phalanges (Borsuk-Bialynicka 1977, Martínez et al. 2004). Similarly, in the unnamed Invernada taxon (González Riga et al. 2008a), no manual phalanges were discovered, although much of the skeleton was exquisitely preserved, including the articulated left fore- and hind limbs with all metacarpals and the complete pes (B.J.G.R. pers. obs.). An important feature of these taxa is that the metacarpals are in contact distally, forming a structure that is more tubular than the metacarpus of other neosauropods (Figure 5c, Epachthosaurus). In this context, the absence of ossified manual phalanges cannot be used as positive evidence (i.e., that these bones were present and subsequently removed by taphonomic processes, as suggested by
Poropat et al. 2016:1012), nor as negative evidence of genuine absence (e.g., Salgado et al. 1997, Wilson 2002). To more rigorously evaluate this character in a given titanosaurian taxon, one must consider the presence or absence of distal articular facets on the metacarpals and the taphonomic context of known specimens.

\section{Lognkosauria}

Lognkosauria is a node-based clade defined as the most recent common ancestor of Mendozasaurus neguyelap and Futalognkosaurus dukei and all descendants (Calvo et al. 2007a). Many previous studies (e.g., Calvo et al. 2007a, b, González Riga and Ortiz David 2014, González Riga et al. 2016) have restricted Lognkosauria to these two taxa, but more recent analyses (Carballido et al. 2017, González Riga et al. 2018) have postulated Argentinosaurus and Patagotitan as lognkosaurians as well; the analysis of Carballido et al. (2017) additionally positioned Drusilasaura, Puertasaurus, and Quetecsaurus within this clade (Figure 10b), whereas that of González Riga et al. (2018) also included Notocolossus (Figure 10d). Intriguingly, most lognkosaurians or putative lognkosaurians are exceedingly large-bodied animals, with Argentinosaurus, Futalognkosaurus, Notocolossus, Patagotitan, and Puertasaurus all being among the largest titanosaurians yet discovered.

In the analysis of González Riga et al. (2018), Lognkosauria was diagnosed by eight synapomorphies, although none of these were regarded as unique to the clade. Two of these morphologies (a deep spinodiapophyseal fossa on the lateral surface of the base of the neural spine in posterior cervical vertebrae and laterally expanded posterior cervical neural spines resulting from expansion of the lateral lamina) are also present in the North American titanosaur Alamosaurus (Tykoski and Fiorillo 2017). From their analysis of 
the data matrix of González Riga and Ortiz David (2014), Tykoski and Fiorillo (2017) obtained a single resolved tree in which Alamosaurus was postulated as the sister taxon of Lognkosauria (Figure 10c).

\section{RECOGNITION OF A NEW TITANOSAURIAN CLADE}

Although many aspects of titanosaurian phylogeny remain unresolved, recent studies have shed considerable light on the interrelationships of taxa within the clade. The phylogenetic definitions of groups such as Saltasaurinae and Lognkosauria are stable, but their taxonomic content has varied depending on the phylogenetic hypothesis recovered. The recent study of González Riga et al. (2018) employed a data matrix of 84 taxa scored for 423 characters. Analysis of this matrix recovered a clade of South American lithostrotian titanosaurs pertaining to Rinconsauria and Lognkosauria. The other principal lithostrotian clade postulated by this analysis primarily includes taxa from Asia and North America plus the Brazilian titanosaur Tapuiasaurus and the Indian Isisaurus (Figure 10d). In the phylogenetic hypothesis of González Riga et al. (2018), Lognkosauria is comprised by Argentinosaurus, Futalognkosaurus, Mendozasaurus, Notocolossus, and Patagotitan.

Carballido et al. (2017), in their study of the giant titanosaur Patagotitan, analyzed a dataset of 405 characters and 87 sauropodomorph taxa (including 28 titanosaurs) that was modified from the matrix of Carballido and Sander (2014). In contrast to most previous studies, Malawisaurus was not recovered as a comparatively basal titanosaur, but instead was placed in a position more derived than Lognkosauria and Rinconsauria. Because Malawisaurus is included in the definition of Lithostrotia (Upchurch et al. 2004), under this phylogenetic hypothesis, members of both LognkosauriaandRinconsauriawouldbeconsidered to be non-lithostrotian titanosaurs (Figure 10b). In
Carballido et al.'s (2017) topology, the colossal Argentinosaurus and Patagotitan are again nested within Lognkosauria, this time accompanied by the similarly gigantic Puertasaurus. Another enormous titanosaur, Notocolossus, is placed as the sister taxon of Lognkosauria, and two main lineages are recovered within Carballido et al.'s (2017) Eutitanosauria: a 'lithostrotian line' that includes Saltasauridae and a second lineage that includes Lognkosauria and Rinconsauria.

The existence of a clade that includes undisputed members of Lognkosauria and Rinconsauria was previously recovered by Tykoski and Fiorillo (2017) based on the data matrix of González Riga and Ortiz David (2014) (Figure 10c). Similarly, Gallina and Apesteguía (2011) also recovered this clade, termed 'node A' in their analysis (Figure 10a). These authors based their study on the dataset of Calvo et al. (2007a) and González Riga et al. (2009), but they added new cranial and postcranial characters, as well as some taxa.

Relevant taxa such as Futalognkosaurus, Mendozasaurus, Muyelensaurus, and Rinconsaurus have been excluded from other recent and pertinent phylogenetic analyses, and as such, it is difficult to further evaluate the existence of the new clade proposed herein. However, although Mendozasaurus and Rinconsaurus were not included in the phylogenetic study of the bizarre Australian titanosaur Savannasaurus (Poropat et al. 2016, dataset of 297 characters and 72 taxa), the new group is supported by the recovery of a Muyelensaurus + (Epachthosaurus + Futalognkosaurus) clade. In this case, the new clade is independent from Nemegtosauridae and Saltasauridae (Poropat et al. 2016, fig. 7). Similarly, although Muyelensaurus and Rinconsaurus were not included in González Riga et al.'s (2016) phylogenetic analysis of Notocolossus (dataset of 350 characters and 33 taxa), a distinct, well-defined clade that includes 


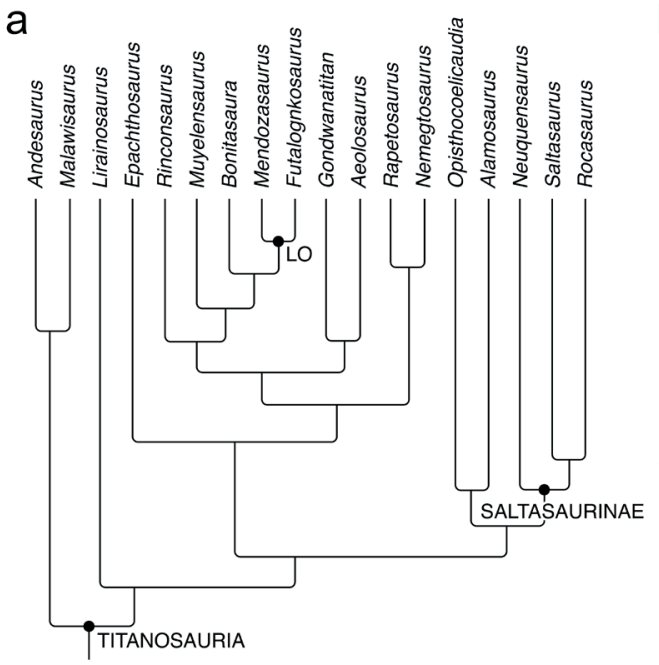

b

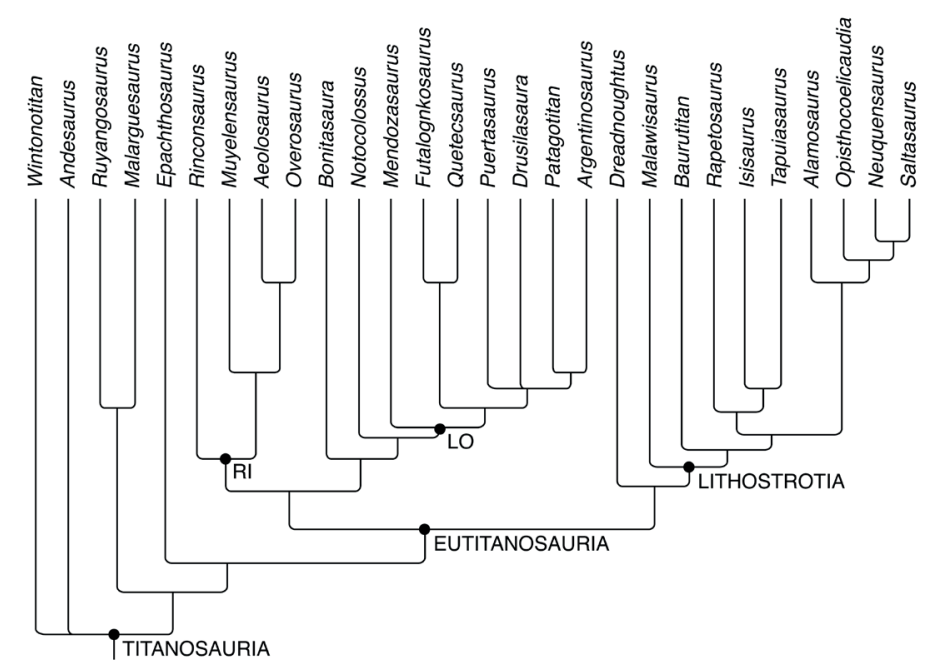

C

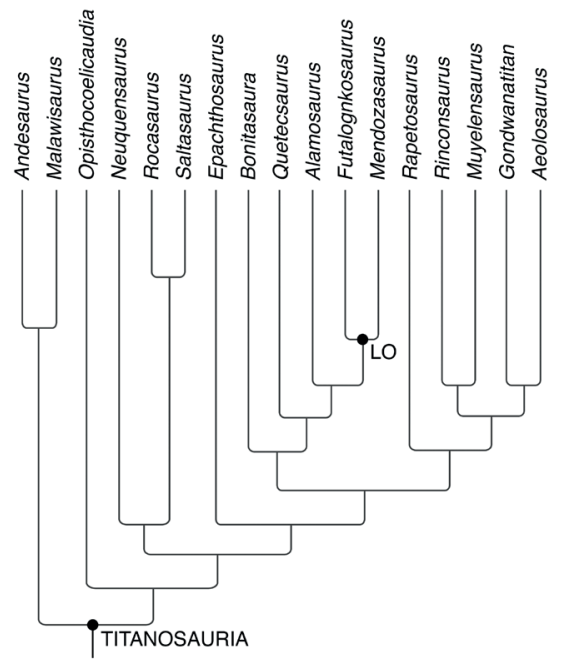

d

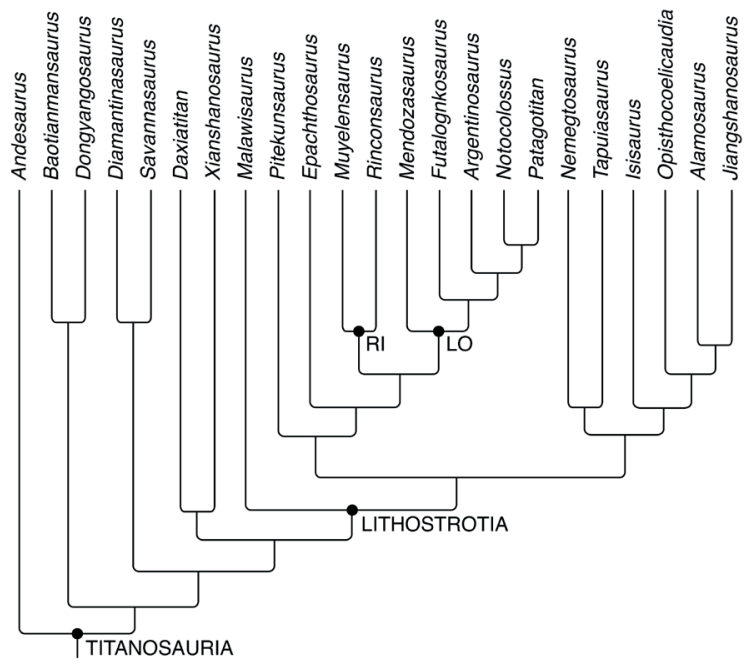

Figure 10 - Four cladistic hypotheses of relationships of titanosaurian taxa. Cladograms have been redrawn and are limited to Titanosauria for ease of comparison. Hypotheses depicted are those of (a) Gallina and Apesteguía (2011), (b) Carballido et al. (2017), (c) Tykoski and Fiorillo (2017), and (d) González Riga et al. (2018). Abbreviations: LO, Lognkosauria, RI, Rinconsauria.

that genus plus Dreadnoughtus, Futalognkosaurus, Mendozasaurus, and Tapuiasaurus was recovered. Finally, though Lacovara et al. (2014, dataset of of 341 characters and 70 taxa) excluded Muyelensaurus and Rinconsaurus from their analysis of Dreadnoughtus, Malawisaurus was recovered as more derived than lognkosaurians, as was also the case in the analysis of Patagotitan (Carballido et al. 2017).

\section{REVISED PHYLOGENETIC ANALYSIS WITH ADDITIONAL CHARACTERS}

We executed a slightly revised phylogenetic analysis that employed the dataset of González Riga et al. (2018, 426 characters and 84 taxa), which in turn was based on that of Mannion et al. (2017) with the addition of some characters (see González Riga et al. 2018 for details). At present study, we added three characters (C424-C426) to 
the matrix; one of these is new and the other two were originally proposed by González Riga et al. (2016) (see Appendix). These added characters are as follows:

C424. Number of phalanges in pedal digit II: three (0), two (1) (González Riga et al. 2016).

C425. Number of phalanges in pedal digit IV: three or more (0), two (1) (modified from González Riga et al. 2016).

C426. Number of phalanges in pedal digit V: two (0), one (1), zero (2) (this paper).

The matrix was analyzed under equal character weighting using TNT (Tree analysis using New Technology) v. 1.1 (Goloboff et al. 2008). The multistate characters $11,14,15,27,40,51,104,122$, $147,148,177,195,205$, and 259 were treated as ordered. In addition, eleven highly incomplete taxa (and therefore unstable) were excluded prior to the analysis (specimen AODF 836, Astrophocaudia, Australodocus, Brontomerus, Fukuititan, Fusuisaurus, Huanghetitan, 'Huanguhetitan' ruyangensis, Liubangosaurus, Mongolosaurus and Tendaguria). First, the data matrix was analyzed using New Technology Search with the functions 'sectorial searches', 'drift' and 'tree fusing'. It was also used 'get tree' from 'driven search' and 'find minimum length' three times. Second, the resultant trees were searching by Traditional Search using the option 'tree bisection-reconstruction'. This process resulted in 660 MPTs of 1741 steps and produced a fairly well-resolved strict consensus tree (Consistency Index, 0.248; Retention index, 0.560 ). The strict consensus of these generates a polytomy of basal titanosaurians but recovers the phylogenetic relationships of lithostrotian taxa within two primary clades: a lineage containing Lognkosauria and Rinconsauria, herein termed Colossosauria, and a clade containing Saltasaurus and other derived taxa.

\section{PHYLOGENETIC DEFINITION OF COLOSSOSAURIA}

Four recent phylogenetic analyses based on largely independent datasets (Gallina and Apesteguía 2011, Carballido et al. 2017, Tykoski and Fiorillo 2017, and González Riga et al. 2018) recovered a clade that includes Lognkosauria and Rinconsauria. Moreover, the results of an amended phylogenetic analysis based on the dataset of González Riga et al. (2018) that includes three additional appendicular characters also supports the existence of this group. Accordingly, we herein propose a new taxon following the tenets of phylogenetic taxonomy (Sereno 2005, Cantino and de Queiroz 2010), as follows:

\section{Colossosauria new taxon}

Etymology. From the ancient Greek colossos, colossus, giant, in reference to the gigantic size of some genera within the clade; from the Greek saurus, lizard, reptile.

Definition.Colossosauria is phylogenetically defined as the most inclusive clade containing Mendozasaurus neguyelap but not Saltasaurus loricatus or Epachthosaurus sciuttoi (stem-based). Specifiers. Mendozasaurus neguyelap González Riga, 2003, Saltasaurus loricatus Bonaparte and Powell, 1980, Epachthosaurus sciuttoi Powell, 1990.

Taxa. Following González Riga et al. (2018) and this paper, Colossosauria includes Argentinosaurus, Futalognkosaurus, Mendozasaurus, Muyelensaurus, Notocolossus, Patagotitan, and Rinconsaurus. After Carballido et al. (2017), the clade comprises the aforementioned taxa plus Aeolosaurus, Bonitasaura, Drusilasaura, Overosaurus, Puertasaurus, and Quetecsaurus.

Diagnosis. Following this paper, Colossosauria is diagnosed by seven ambiguous synapomorphies: humerus, minimum mediolateral width divided by proximodistal length less than 0.15 (Character 42, state 1), middle-posterior dorsal neural arches with posterior centroparapophyseal lamina (character 
148, state 1), middle-posterior dorsal neural spines vertical or slightly posterodorsal (character 164, state 0), middle-posterior dorsal neural arches, neural canal in anterior view enclosed in a deep fossa in the dorsal surface of the centrum (character 338 , state 1), glenoid does not expand strongly laterally relative to the lateral surface of the coracoid (character 361, state 0), humerus, deltopectoral crest, mediolateral thickness of anterior attachment surface with distal half mediolaterally expanded relative to proximal half (character 369, state 0), metacarpal $\mathrm{V}$ with dorsomedial margin of distal third forming a prominent ridge or flange (character 420, state 1).

Observations. The name proposed herein does not affect the previous nomenclature of other titanosaurian clades. Figure 11 shows the position of the clade Colossosauria.

\section{CONCLUSIONS}

Systematic and phylogenetic studies of titanosaurian sauropod dinosaurs have often focused greater attention on the postcranial axial skeleton than on the appendicular skeleton. Nevertheless, this practice has changed in recent years alongside

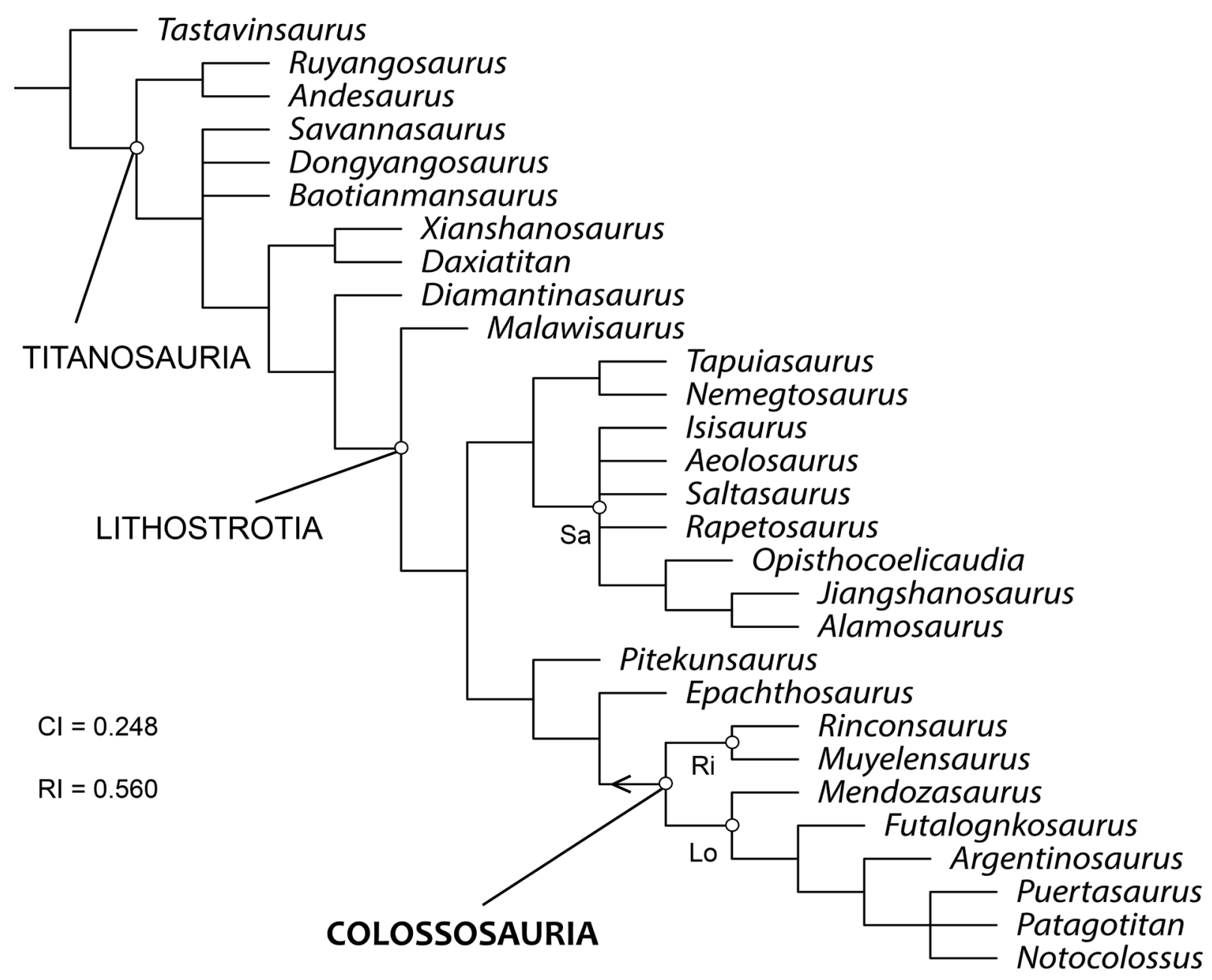

Figure 11 - Strict consensus cladogram (limited to Titanosauria) generated from a revised analysis of the data matrix of González Riga et al. (2018) with the addition of three characters (this paper), showing the position and taxonomic content of the newlyrecognized stem-based clade Colossosauria. Abbreviations: Lo, Lognkosauria, Ri, Rinconsauria, Sa, Saltasauridae. 
discoveries of new specimens that preserve the appendicular skeleton in its entirety, or nearly so. These fossils have provided a wealth of new anatomical and paleobiological information on titanosaurs, a group that is characterized by marked variation in both body size and morphology.

An overview of the appendicular skeletal morphology of titanosaurian taxa from South America indicates that this part of the skeleton exhibits greater anatomical diversity than was initially appreciated. Detailed comparative studies of each of these appendicular elements and skeletal regions would likely yield additional character information useful for phylogenetic analyses. From a systematic point of view, the present review shows that there is no definitive consensus on the appendicular character states that serve as synapomorphies for Titanosauria and Lithostrotia. However, within Titanosauria, recent phylogenetic analyses confirm the presence of a titanosaurian lineage that differs from the 'Saltasaurinae line.' Four recent cladistic studies based on largely independent datasets have recovered this new clade, which is herein termed Colossosauria. At present, this clade is mainly comprised by taxa belonging to Rinconsauria and Lognkosauria, the latter including several exceptionally gigantic species.

\section{ACKNOWLEDGMENTS}

We are grateful to the many people who have collaborated with us in collecting, preparing, and studying South American titanosaur fossils over the years. We also acknowledge those who have helped us study South American sauropod material in their care, in particular Jorge Calvo (MUCPv), Rubén Martínez, Gabriel Casal, and Marcelo Luna (UNPSJB), and Jaime Powell (PVL). Case Miller and Andrew McAfee (CM) provided assistance with the bibliography and Figure 10, respectively. We are also grateful the reviewers Pedro Mocho
(Natural History Museum of Los Angeles County), Jorge Calvo (Centro Paleontológico Lago Barreales, Universidad Nacional del Comahue), and Stephen Poropat (Swinburne University of Technology), whose insightful comments improved the final paper. Funding was provided by projects of the Agencia Nacional de Promoción Científica y Tecnológica (PICT), the Universidad Nacional de Cuyo-SECYT, and CONICET-PIP to B.J.G.R. A.W.A.K. acknowledges the Conselho Nacional de Desenvolvimento Científico e Tecnológico (CNPq, \#313461/2018-0) and the Fundação Carlos Chagas Filho de Amparo a Pesquisa do Estado do Rio de Janeiro (FAPERJ, \#E-26/202.905/2018).

\section{AUTHOR CONTRIBUTIONS}

The goals of this paper were proposed by B.J.G.R. Anatomical description was performed by B.J.G.R., M.C.L., A.O., and L.M.I. Phylogenetic analysis was performed by L.D.O.D., A.O., and B.J.G.R. The discussion was written by B.J.G.R., M.C.L., A.O., L.M.I., L.D.O.D., and A.W.A.K. The English revision was completed by M.C.L. The figures were done by L.D.O.D and B.J.G.R. The tables were made by M.C.L., B.J.G.R., and L.M.I.

\section{REFERENCES}

APESTEGUÍA S. 2004. Bonitasaura salgadoi gen. et sp. nov.: a beaked sauropod from the Late Cretaceous of Patagonia. Naturwissenschaften 91: 493-497.

APESTEGUÍA S. 2005. Evolution of the titanosaur metacarpus. In: Tidwell V, Carpenter K (Eds), ThunderLizards: The Sauropodomorph Dinosaurs. Bloomington, Indiana University Press: 321-345.

BATES K, FALKINGHAM P, MACAULAY S, BRASSEY C AND MAIDMENT S. 2015. Downsizing a giant: reevaluating Dreadnoughtus body mass. Biol Let 11: 20150215.

BONAPARTE J AND CORIA R. 1993. Un nuevo y gigantesco saurópodo titanosaurio de la Formación Río Limay (Albiano-Cenomaniano) de la Provincia del Neuquén, Argentina. Ameghiniana 30: 271-282.

BONAPARTE J. 1996. Cretaceous tetrapods of Argentina. Münch Geowis Abhand 30: 73-130. 
BONAPARTE J. 1999. Evolución de las vértebras presacras en Sauropodomorpha. Ameghiniana 36: 115-187.

BONAPARTE J AND POWELL J. 1980. A continental assemblage of tetrapods from the Upper Cretaceous of northwestern Argentina (Sauropoda-CoelurosauriaCarnosauria-Aves). Mém Soc Géol France 139: 19-28.

BONAPARTE J, GONZÁLEZ RIGA B AND APESTEGUÍA S. 2006. Ligabuesaurus leanzai gen. et sp. nov. (Dinosauria, Sauropoda), a new titanosaur from the Lohan Cura Formation (Aptian, Lower Cretaceous) of Neuquén, Patagonia, Argentina. Cret Res 27: 364-376.

BONNAN M. 2003. The evolution of manus shape in sauropod dinosaurs: implications for functional morphology, forelimb orientation, and phylogeny. J Verteb Paleont 23: 595-613.

BONNAN M. 2005. Pes anatomy in sauropod dinosaurs: implications for functional morphology, evolution, and phylogeny. In: Tidwell V and Carpenter K (Eds), ThunderLizards: The Sauropodomorph Dinosaurs. Bloomington: Indiana University Press: 346-380.

BORSUK-BIALYNICKA M. 1977. A new camarasaurid sauropod Opisthocoelicaudia skarzynskii, gen. n., sp. n. from the Upper Cretaceous of Mongolia. Palaeont Pol 37: $1-64$.

CALVO J. 1999. Dinosaurs and other vertebrates of the Lake Ezequiel Ramos Mexía area, Neuquén-Patagonia, Argentina. Nat Scien Mus Monogr 15: 13-45.

CALVO J. 2014. New fossil remains of Futalognkosaurus dukei (Sauropoda, Titanosauria) from the Late Cretaceous of Neuquén, Argentina. In: Cerdeño E (Ed), $4^{\text {th }}$ International Palaeontological Congress, "The History of Life: A View from the Southern Hemisphere," Abstract Volume. Mendoza: International Palaeontological Association: 325.

CALVO J AND BONAPARTE J. 1991. Andesaurus delgadoi gen. et sp. nov. (Saurischia-Sauropoda), dinosaurio Titanosauridae de la Formación Río Limay (AlbianoCenomaniano), Neuquén, Argentina. Ameghiniana 28: 303-310.

CALVO J AND GONZÁLEZ RIGA B. 2003. Rinconsaurus caudamirus gen. et sp. nov., a new titanosaurid (Dinosauria, Sauropoda) from the Late Cretaceous of Patagonia, Argentina. Rev Geol Chile 30: 333-353.

CALVO J, GONZÁLEZ RIGA B AND PORFIRI J. 2007c. A new titanosaur sauropod from the Late Cretaceous of Neuquén, Patagonia, Argentina. Arq Mus Nac, Rio de Janeiro 65: 485-504.

CALVO J AND PORFIRI J. 2010. Panamericansaurus schroederi gen. nov. sp. nov. Un nuevo Sauropoda (Titanosauridae-Aeolosaurini) de la Provincia del Neuquén, Cretácico Superior de Patagonia, Argentina. Braz Geograp Jour: Geosc Hum Resear Med 1: 100-115.

CALVO J, PORFIRI J, GONZÁLEZ RIGA B AND KELLNER A. 2007a. A new Cretaceous terrestrial ecosystem from
Gondwana with the description of a new sauropod dinosaur. An Acad Bras Cienc 79: 529-541.

CALVO J, PORFIRI J, GONZÁLEZ RIGA B AND KELLNER A. 2007b. Anatomy of Futalognkosaurus dukei Calvo, Porfiri, González Riga \& Kellner, 2007 (Dinosauria, Titanosauridae) from the Neuquén Group (Late Cretaceous), Patagonia, Argentina. Arq Mus Nac, Rio de Janeiro 65: 511-526.

CAMPOS D, KELLNER A, BERTINI R AND SANTUCCI R. 2005. On a titanosaurid (Dinosauria, Sauropoda) vertebral column from the Bauru Group, Late Cretaceous of Brazil. Arq Mus Nac, Rio de Janeiro 63: 565-593.

CANTINO P AND DE QUEIROZ K. 2010. International code of phylogenetic nomenclature. Version 4c (Internet). Available from http://www.ohio.edu/phylocode/.

CARBALLIDO J, POL D, CERDA I AND SALGADO L. 2011. The osteology of Chubutisaurus insignis del Corro, 1975 (Dinosauria: Neosauropoda) from the 'middle' Cretaceous of central Patagonia, Argentina. J Verteb Paleont 31: 93-110.

CARBALLIDO J, POL D, OTERO A, CERDA I, SALGADO L, GARRIDO A, RAMEZANI J, CÚNEO N AND KRAUSE J. 2017. A new giant titanosaur sheds light on body mass evolution among sauropod dinosaurs. Proceed Roy Soc B 284: 20171219.

CARBALLIDO J AND SANDER P. 2014. Postcranial axial skeleton of Europasaurus holgeri (Dinosauria, Sauropoda) from the Upper Jurassic of Germany: implications for sauropod ontogeny and phylogenetic relationships of basal Macronaria. J System Palaeont 12: 335-387.

CARRANO M. 2005. The evolution of sauropod locomotion: morphological diversity of a secondarily quadrupedal radiation. In: Curry Rogers K, Wilson J (Eds), The Sauropods: Evolution and Paleobiology. Berkeley: Univ of California Press: 229-251.

CERDA I, SALGADO L AND POWELL J. 2012. Extreme postcranial pneumaticity in sauropod dinosaurs from South America. Paläontol Zeitschrift 86: 441-449.

COOMBS W. 1975. Sauropod habits and habitats. Palaeog Palaeocl Palaeoec 17: 1-33.

CORIA R, FILIPPI L, CHIAPPE L, GARCÍA R AND ARCUCCI A. 2013. Overosaurus paradasorum gen. et sp. nov., a new sauropod dinosaur (Titanosauria: Lithostrotia) from the Late Cretaceous of Neuquén, Patagonia, Argentina. Zootaxa 3683: 357-376.

CURRY ROGERS K. 2005. Titanosauria: a phylogenetic overview. In: Curry Rogers K and Wilson J (Eds), The Sauropods: Evolution and Paleobiology. Berkeley: Univ of California Press: 50-103.

CURRY ROGERS K. 2009. The postcranial osteology of Rapetosaurus krausei (Sauropoda: Titanosauria) from the Late Cretaceous of Madagascar. J Verteb Paleont 29: 10461086. 
CURRY ROGERS K AND FORSTER C. 2001. The last of the dinosaur titans: a new sauropod from Madagascar. Nature 412: 530-534.

CURRY ROGERS K AND FORSTER C. 2004. The skull of Rapetosaurus krausei (Sauropoda: Titanosauria) from the Late Cretaceous of Madagascar. J Verteb Paleont 24: 121144.

CURRY ROGERS K AND WILSON J. 2014. Vahiny depereti, gen. et sp. nov., a new titanosaur (Dinosauria, Sauropoda) from the Upper Cretaceous Maevarano Formation, Madagascar. J Verteb Paleont 34: 606-617.

D'EMIC M. 2012. The early evolution of titanosauriform sauropod dinosaurs. Zool J Lin Soc 166: 624-671.

D’EMIC M, WILSON J AND WILLIAMSON T. 2011. A sauropod dinosaur pes from the latest Cretaceous of North America and the validity of Alamosaurus sanjuanensis (Sauropoda, Titanosauria). J Verteb Paleont 31: 10721079.

DE SOUZA CARVALHO I, SALGADO L, LINDOSO R, DE ARAÚJO-JÚNIOR H, NOGUEIRA F AND SOARES J. 2017. A new basal titanosaur (Dinosauria, Sauropoda) from the Lower Cretaceous of Brazil. J S Am Earth Sci 75: 74-84.

DÍEZ DÍAZ V, MOCHO P, PÁRAMO A, ESCASO F, MARCOS-FERNÁNDEZ F, SANZ J AND ORTEGA F. 2016. A new titanosaur (Dinosauria, Sauropoda) from the Upper Cretaceous of Lo Hueco (Cuenca, Spain). Cret Res 68: 49-60.

FARLOW J. 1992. Sauropod tracks and trackmakers: integrating the ichnological and skeletal records. Zubía 10: 89-138.

FILIPPI L AND GARRIDO A. 2008. Pitekunsaurus macayai gen. et sp. nov., nuevo titanosaurio (Saurischia, Sauropoda) del Cretácico Superior de la Cuenca Neuquina, Argentina. Ameghiniana 45: 575-590.

FILIPPI L, GARCÍA R AND GARRIDO A. 2011a. A new titanosaur sauropod dinosaur from the Upper Cretaceous of North Patagonia, Argentina. Acta Palaeont Pol 56: 505520.

FILIPPI L, CANUDO J, SALGADO J, GARRIDO A, GARCÍA R, CERDA I AND OTERO A. 2011b. A new sauropod titanosaur from the Plottier Formation (Upper Cretaceous) of Patagonia (Argentina). Geol Acta 9: 1-12.

FILIPPI L, SALGADO L AND GARRIDO A. 2019. A new giant basal titanosaur sauropod in the Upper Cretaceous (Coniacian) of the Neuquén Basin, Argentina. Cret Res 100: $61-81$.

GALLINAP. 2011. Notes on the axial skeleton of the titanosaur Bonitasaura salgadoi (Dinosauria-Sauropoda). An Acad Bras Cienc 83: 235-246.

GALLINA P AND APESTEGUÍA S. 2011. Cranial anatomy and phylogenetic position of the titanosaurian sauropod Bonitasaura salgadoi. Acta Palaeont Pol 56: 45-60.
GALLINA P AND APESTEGUÍA S. 2015. Postcranial anatomy of Bonitasaura salgadoi (Sauropoda, Titanosauria) from the Late Cretaceous of Patagonia. J Verteb Paleont 35: e924957.

GALLINA P AND OTERO A. 2015. Reassessment of Laplatasaurus araukanicus (Sauropoda: Titanosauria) from the Upper Cretaceous of Patagonia, Argentina. Ameghiniana 52: 487-501.

GALTON P AND UPCHURCH P. 2004. Prosauropoda. In: Weishampel D, Dodson P, Osmólska H (Eds), The Dinosauria (Second Edition). Berkeley: Univ of California Press: 232-258.

GILMORE C. 1946. Reptilian fauna of the North Horn Formation of central Utah. US Depart Int Prof Paper 210C: $1-53$.

GIMÉNEZ O. 1992. Estudio preliminar del miembro anterior de los sauropodos titanosauridos. Ameghiniana 30: 154.

GOLOBOFF P, FARRIS J AND NIXON K. 2008. TNT, a free program for phylogenetic analysis. Cladistics 24: 774-786.

GONZÁLEZ RIGA B. 2003. A new titanosaur (Dinosauria, Sauropoda) from the Upper Cretaceous of Mendoza Province, Argentina. Ameghiniana 40: 155-172.

GONZÁLEZ RIGA B. 2005. Nuevos restos fósiles de Mendozasaurus neguyelap (Sauropoda, Titanosauria) del Cretácico tardío de Mendoza, Argentina. Ameghiniana 42: 535-548.

GONZÁLEZ RIGA B. 2011. Paleobiology of South American titanosaurs. In: Calvo J, Porfiri J, González Riga B and Dos Santos D (Eds), Paleontología y Dinosaurios desde América Latina. Mendoza: Universidad Nacional de Cuyo: 125-141.

GONZÁLEZ RIGA B AND CALVO J. 2009. A new widegauge sauropod track site from the Late Cretaceous of Mendoza, Neuquén Basin, Argentina. Palaeontology 52: 631-640.

GONZÁLEZ RIGA B, CALVO J AND PORFIRI J. 2008a. An articulated titanosaur from Patagonia (Argentina): new evidence of neosauropod pedal evolution. Palaeoworld 17: 33-40.

GONZÁlEZ RIGA B, CALVO J AND PREVITERA E. 2008b. Taphonomic analyses of titanosaur sauropods from the Neuquén Basin (Argentina) and their implications in systematic studies. In: Colectivo Arqueológico y Paleontológico de Salas (Eds), IV Jornadas Internacionales sobre Paleontología de Dinosaurios y su Entorno. Burgos: Colectivo Arqueológico y Paleontológico de Salas de los Infantes: 235-241.

GONZÁLEZ RIGA B, LAMANNA M, ORTIZ DAVID L, CALVO J AND CORIA J. 2016. A gigantic new dinosaur from Argentina and the evolution of the sauropod hind foot. Scient Rep 6: 19165.

GONZÁLEZ RIGA B, MANNION P, POROPAT S, ORTIZ DAVID L AND CORIA J. 2018. Osteology of the Late 
Cretaceous Argentinean sauropod dinosaur Mendozasaurus neguyelap: implications for basal titanosaur relationships. Zool J Lin Soc 184: 136-181.

GONZÁLEZ RIGA B AND ORTIZ DAVID L. 2014. A new titanosaur (Dinosauria, Sauropoda) from the Upper Cretaceous (Cerro Lisandro Formation) of Mendoza Province, Argentina. Ameghiniana 51: 3-25.

GONZÁLEZ RIGA B, ORTIZ DAVID L, TOMASELLI M, CANDEIRO C, CORIA J AND PRÁMPARO M. 2015. Sauropod and theropod dinosaur tracks from the Upper Cretaceous of Mendoza (Argentina): trackmakers and anatomical evidences. J S Am Earth Sci 61: 134-141.

GONZÁlEZ RIGA B, PREVITERA E AND PIRRONE C. 2009. Malarguesaurus florenciae gen. et sp. nov., a new titanosauriform (Dinosauria, Sauropoda) from the Upper Cretaceous of Mendoza, Argentina. Cret Res 30: 135-148.

GONZÁLEZ RIGA B AND TOMASELLI M. 2019. Different trackway patterns in titanosaur sauropods: analysis of new Titanopodus tracks from the Upper Cretaceous of Mendoza, Neuquén Basin, Argentina. Cret Res 93: 49-59.

GORSCAK E AND O'CONNOR P. 2016. Time-calibrated models support congruency between Cretaceous continental rifting and titanosaurian evolutionary history. Biol Let 12: 20151047.

GORSCAK E, O'CONNOR P, STEVENS N AND ROBERTS E. 2014. The basal titanosaurian Rukwatitan bisepultus (Dinosauria, Sauropoda) from the middle Cretaceous Galula Formation, Rukwa Rift Basin, southwestern Tanzania. J Verteb Paleont 34: 1133-1154.

GORSCAK E, O'CONNOR P, ROBERTS E AND STEVENS N. 2017. The second titanosaurian (Dinosauria: Sauropoda) from the middle Cretaceous Galula Formation, southwestern Tanzania, with remarks on African titanosaurian diversity. J Verteb Paleont 37: e1343250.

HATCHER J. 1901. Diplodocus (Marsh): its osteology, taxonomy, and probable habits, with a restoration of the skeleton. Mem Carneg Mus 1: 1-63.

HE X, LI K AND CAI K. 1988. The Middle Jurassic Dinosaur Fauna from Dashanpu, Zigong, Sichuan, Vol. IV. Sauropod Dinosaurs (2), Omeisaurus tianfuensis. Chengdu: Sichuan Scient Tech Publ House.

HOCKNULL S, WHITE M, TISCHLER T, COOK A, CALLEJA N, SLOAN T AND ELLIOTT D. 2009. New mid-Cretaceous (latest Albian) dinosaurs from Winton, Queensland, Australia. PLoS ONE 4: e6190.

HUENE F. 1929. Los saurisquios y ornitisquios del Cretáceo Argentino. An Mus La Plata 3: 1-196.

JAIN S AND BANDYOPADHYAY S. 1997. New titanosaurid (Dinosauria: Sauropoda) from the Late Cretaceous of central India. J Verteb Paleont 17: 114-136.

JANENSCH W. 1961. Die Gliedmaszen und Gliedmaszengürtel der Sauropoden der TendaguruSchichten. Palaeontographica Suppl 7: 177-235.
JUÁREZ VALIERI R AND CALVO J. 2011. Revision of MUCPv 204, a Senonian basal titanosaur from northern Patagonia. In: Calvo J, Porfiri J, González Riga B and Dos Santos D (Eds), Paleontología y Dinosaurios desde América Latina. Mendoza: Universidad Nacional de Cuyo: 143-152.

KELLNER A, CAMPOS D, DE AZEVEDO S, TROTTA M, HENRIQUES D, CRAIK M AND DE PAULA SILVA H. 2006. On a new titanosaur sauropod from the Bauru Group, Late Cretaceous of Brazil. Bol Mus Nac, Nova Série 74: 1-31.

KELLNER A AND DE AZEVEDO S. 1999. A new sauropod dinosaur (Titanosauria) from the Late Cretaceous of Brazil. Nat Scien Mus Monogr 15: 111-142.

KELLNER A, RUBILAR-ROGERS D, VARGAS A AND SUAREZ M. 2011. A new titanosaur sauropod from the Atacama Desert, Chile. An Acad Bras Cienc 83: 211-219.

KLINKHAMER A, MALLISON H, POROPAT S, SINAPIUS G AND WROE S. 2018. Three-dimensional musculoskeletal modelling of the sauropodomorph hind limb: the effect of postural change on muscle leverage. Anat Rec 301: 2145-2163.

LACOVARA K ET AL. 2014. A gigantic, exceptionally complete titanosaurian sauropod dinosaur from southern Patagonia, Argentina. Scient Rep 4: 6196.

LOCKLEY M, FARLOW J AND MEYER C. 1994. Brontopodus and Parabrontopodus ichnogen. nov. and the significance of wide and narrow-gauge sauropod trackways. Gaia 10: 233-248.

LOCKLEY M, SCHULP A, MEYER C, LEONARDI G AND KERUMBA MAMANI D. 2002. Titanosaurid trackways from the Upper Cretaceous of Bolivia: evidence for large manus, wide-gauge locomotion and gregarious behaviour. Cret Res 23: 383-400.

LYDEKKER R. 1893. The dinosaurs of Patagonia. An Mus La Plata 2: 1-14.

MACHADO E, AVILLA L, NAVA W, CAMPOS D AND KELLNER A. 2013. A new titanosaur sauropod from the Late Cretaceous of Brazil. Zootaxa 3701: 301-321.

MANNION P, ALLAIN R AND MOINE O. 2017. The earliest known titanosauriform sauropod dinosaur and the evolution of Brachiosauridae. PeerJ 5: e3217.

MANNION P, BENSON R, UPCHURCH P, BUTLER R, CARRANO M AND BARRETT P. 2011. A temperate palaeodiversity peak in Mesozoic dinosaurs and evidence for Late Cretaceous geographical partitioning. Glob Ecol Biog 21: 898-908.

MANNION P AND CALVO J. 2011. Anatomy of the basal titanosaur (Dinosauria, Sauropoda) Andesaurus delgadoi from the mid-Cretaceous (Albian-early Cenomanian) Río Limay Formation, Neuquén Province, Argentina: implications for titanosaur systematics. Zool J Lin Soc 163: $155-181$. 
MANNION P AND OTERO A. 2012. A reappraisal of the Late Cretaceous Argentinean sauropod dinosaur Argyrosaurus superbus, with a description of a new titanosaur genus. J Verteb Paleont 32: 614-638.

MANNION P, UPCHURCH P, BARNES R AND MATEUS O. 2013. Osteology of the Late Jurassic Portuguese sauropod dinosaur Lusotitan atalaiensis (Macronaria) and the evolutionary history of basal titanosauriforms. Zool J Lin Soc 168: 98-206.

MARTINELLI A AND FORASIEPI A. 2004. Late Cretaceous vertebrates from Bajo de Santa Rosa (Allen Formation), Río Negro Province, Argentina, with the description of a new sauropod dinosaur (Titanosauridae). Rev Mus Arg de Cienc Nat, Nueva Serie 6: 257-305.

MARTÍNEZ R, GIMÉNEZ O, RODRÍGUEZ J, LUNA M AND LAMANNA M. 2004. An articulated specimen of the basal titanosaurian (Dinosauria: Sauropoda) Epachthosaurus sciuttoi from the early Late Cretaceous Bajo Barreal Formation of Chubut Province, Argentina. J Verteb Paleont 24: 107-120.

MATEUS O, JACOBS L, SCHULPA, POLCYN M, TAVARES T, BUTA NETO A, MORAIS M AND ANTUNES M. 2011. Angolatitan adamastor, a new sauropod dinosaur and the first record from Angola. An Acad Bras Cienc 83: 221-233.

MCINTOSH J. 1990. Sauropoda. In: Weishampel D, Dodson P, Osmólska H (Eds), The Dinosauria. Berkeley: Univ of California Press: 345-401.

MCINTOSH J, MILES C, CLOWARD K AND PARKER J. 1996. A nearly complete skeleton of Camarasaurus. Bull Gunma Mus Nat Hist 1: 1-87.

MEERS M. 2003. Crocodylian forelimb musculature and its relevance to Archosauria. Anat Rec Part A 274: 892-916.

NAVARRETE C, CASAL G AND MARTÍNEZ R. 2011. Drusilasaura deseadensis gen. et sp. nov., un nuevo titanosaurio (Dinosauria-Sauropoda), de la Formación Bajo Barreal, Cretácico Superior del norte de Santa Cruz, Argentina. Rev Bras Paleont 14: 1-14.

NOVAS F, SALGADO L, CALVO J AND AGNOLÍN F. 2005. Giant titanosaur (Dinosauria, Sauropoda) from the Late Cretaceous of Patagonia. Rev Mus Arg Cienc Nat, Nueva Serie 7: 37-41.

OSBORN H. 1904. Manus, sacrum, and caudals of Sauropoda. Bull Am Mus Nat Hist 20: 181-190.

OSBORN H AND MOOK C. 1921. Camarasaurus, Amphicoelias, and other sauropods of Cope. Mem Am Mus Nat Hist 3: 247-387.

OTERO A. 2010. The appendicular skeleton of Neuquensaurus, a Late Cretaceous saltasaurine sauropod from Patagonia, Argentina. Acta Palaeont Pol 55: 299-326.

OTERO A. 2018. Forelimb musculature and osteological correlates in Sauropodomorpha (Dinosauria, Saurischia). PLoS ONE 13: e0198988.
OTERO A AND SALGADO L. 2015. El registro de Sauropodomorpha (Dinosauria) de la Argentina. In: Fernández M and Herrera Y (Eds), Reptiles Extintos Volumen en Homenaje a Zulma Gasparini. Buenos Aires: Publicación Electrónica Asoc Paleont Arg 15: 69-89.

OTERO A AND VIZCAÍNO S. 2008. Hindlimb musculature and function of Neuquensaurus australis (Lydekker) (Sauropoda: Titanosauria). Ameghiniana 45: 333-348.

OUYANG H AND YE Y. 2002. The first mamenchisaurian skeleton with complete skull: Mamenchisaurus youngi. Chengdu: Sichuan Scient Tech Press: 1-111.

POROPAT S, UPCHURCH P, MANNION P, HOCKNULL S, KEAR B, SLOAN T, SINAPIUS G AND ELLIOTT D. 2015. Revision of the sauropod dinosaur Diamantinasaurus matildae Hocknull et al. 2009 from the middle Cretaceous of Australia: implications for Gondwanan titanosauriform dispersal. Gond Res 27: 995-1033.

POROPAT S ET AL. 2016. New Australian sauropods shed light on Cretaceous dinosaur palaeobiogeography. Scient Rep 6: 34467.

POWELL J. 1990. Epachthosaurus sciuttoi (gen. et sp. nov.) un dinosaurio saurópodo del Cretácico de Patagonia (Provincia de Chubut, Argentina). V Congreso Argentino de Paleontología y Bioestratigrafía, Tucumán, Actas 1: 123-128.

POWELL J. 1992. Osteología de Saltasaurus loricatus (Sauropoda - Titanosauridae) del Cretácico Superior del noroeste Argentino. In: Sanz J and Buscalioni A (Eds), Los Dinosaurios y su Entorno Biótico. Cuenca: Instituto 'Juan de Valdés': 165-230.

POWELL J. 2003. Revision of South American titanosaurid dinosaurs: paleobiological, palaeobiogeographical and phylogenetic aspects. Rec Queen Vict Mus 111: 1-173.

ROMER A. 1968. Notes and Comments on Vertebrate Paleontology. Chicago: Univ of Chicago Press, 304 p.

SALGADO L. 1996. Pellegrinisaurus powelli nov. gen. et sp. (Sauropoda, Titanosauridae) from the Upper Cretaceous of Lago Pellegrini, northwestern Patagonia, Argentina. Ameghiniana 33: 355-365.

SALGADO L AND AZPILICUETA C. 2000. Un nuevo saltasaurino (Sauropoda, Titanosauridae) de la provincia de Río Negro (Formación Allen, Cretácico Superior), Patagonia, Argentina. Ameghiniana 37: 259-264.

SALGADO L AND DE SOUZA CARVALHO I. 2008. Uberabatitan ribeiroi, a new titanosaur from the Marília Formation (Bauru Group, Upper Cretaceous), Minas Gerais, Brazil. Palaeontology 51: 881-901.

SALGADO L, CORIA R AND CALVO J. 1997. Evolution of titanosaurid sauropods. I: phylogenetic analysis based on the postcranial evidence. Ameghiniana 34: 3-32.

SALGADO L, APESTEGUÍA S AND HEREDIA S. 2005. A new specimen of Neuquensaurus australis, a Late 
Cretaceous saltasaurine titanosaur from north Patagonia. J Verteb Paleont 25: 623-634.

SALGADO L, GALLINA P AND PAULINA CARABAJAL A. 2015. Redescription of Bonatitan reigi (Sauropoda: Titanosauria), from the Campanian-Maastrichtian of the Río Negro Province (Argentina). Hist Biol 27: 525-548.

SALLAM H, GORSCAK E, O'CONNOR P, EL-DAWOUDI I, EL-SAYED S, SABER S, KORA M, SERTICH J, SEIFFERT E AND LAMANNA M. 2018. New Egyptian sauropod reveals Late Cretaceous dinosaur dispersal between Europe and Africa. Nat Ecol Evol 2: 445-451.

SANDER P ET AL. 2011. Biology of the sauropod dinosaurs: the evolution of gigantism. Biol Rev 86: 117-155.

SANTUCCI R AND DE ARRUDA-CAMPOS A. 2011. A new sauropod (Macronaria, Titanosauria) from the Adamantina Formation, Bauru Group, Upper Cretaceous of Brazil and the phylogenetic relationships of Aeolosaurini. Zootaxa 3085: 1-33.

SANZ J, POWELL J, LE LOEUFF J, MARTÍNEZ R AND PEREDA SUBERBIOLA X. 1999. Sauropod remains from the Upper Cretaceous of Laño (northcentral Spain). Titanosaur phylogenetic relationships. Estud Mus Cienc Nat Alava 14: 235-255.

SERENO P. 2005. The logical basis of phylogenetic taxonomy. Syst Biol 54: 595-619.

SIMÓN M, SALGADO L AND CALVO J. 2018. A new titanosaur sauropod from the Upper Cretaceous of Patagonia, Neuquén Province, Argentina. Ameghiniana 55: 1-29.

SMITH J, LAMANNA M, LACOVARA K, DODSON P, SMITH J, POOLE J, GIEGENGACK R AND ATTIA Y. 2001. A giant sauropod dinosaur from an Upper Cretaceous mangrove deposit in Egypt. Science 292: 1704-1706.

STEVENS K, ERNST S AND MARTY D. 2016. Uncertainty and ambiguity in the interpretation of sauropod trackways. In: Falkingham P, Marty D, Richter A (Eds), Dinosaur Tracks - The Next Steps. Bloomington: Indiana University Press: 227-243.

TYKOSKI R AND FIORILLO A. 2017. An articulated cervical series of Alamosaurus sanjuanensis Gilmore, 1922 (Dinosauria, Sauropoda) from Texas: new perspective on the relationships of North America's last giant sauropod. J Syst Palaeont 15: 339-364.

ULLMANN P AND LACOVARA K. 2016. Appendicular osteology of Dreadnoughtus schrani, a giant titanosaurian (Sauropoda, Titanosauria) from the Upper Cretaceous of Patagonia, Argentina. J Verteb Paleont 36: e1225303.

UPCHURCH P. 1995. The evolutionary history of sauropod dinosaurs. Phil Trans Roy Soc London B 349: 365-390.

UPCHURCH P. 1998. The phylogenetic relationships of sauropod dinosaurs. Zool J Linn Soc 124: 43-103.

UPCHURCH P, BARRETT P AND DODSON P. 2004. Sauropoda. In: Weishampel D, Dodson P, Osmólska H
(Eds), The Dinosauria (Second Edition). Berkeley: Univ of California Press: 259-322.

UPCHURCH P, MANNION P AND TAYLOR M. 2015. The anatomy and phylogenetic relationships of "Pelorosaurus" becklesii (Neosauropoda, Macronaria) from the Early Cretaceous of England. PLoS ONE 10: e0125819.

VILA B, OMS O, MARMI J AND GALOBART A. 2008. Tracking Fumanya footprints (Maastrichtian, Pyrenees): historical and ichnological overview. Oryctos 8: 115-130.

VOEGELE K, LAMANNA M AND LACOVARA K. 2017. Osteology of the dorsal vertebrae of the giant titanosaurian sauropod dinosaur Dreadnoughtus schrani from the Late Cretaceous of Argentina. Acta Palaeont Pol 62: 667-681.

WILSON J. 1999. A nomenclature for vertebral laminae in sauropods and other saurischian dinosaurs. J Verteb Paleont 19: 639-653.

WILSON J. 2002. Sauropod dinosaur phylogeny: critique and cladistic analysis. Zool J Linn Soc 136: 217-276.

WILSON J. 2006. An overview of titanosaur evolution and phylogeny. In: Actas de las III Jornadas Internacionales sobre Paleontología de Dinosaurios y su Entorno. Burgos: Colectivo Arqueológico-Paleontológico de Salas de los Infantes: 169-190.

WILSON J. 2012. New vertebral laminae and patterns of serial variation in vertebral laminae of sauropod dinosaurs. Contrib Mus Paleontol, Univ of Michigan 32: 91-110.

WILSON J, BARRETT P AND CARRANO M. 2011. An associated partial skeleton of Jainosaurus cf. septentrionalis (Dinosauria: Sauropoda) from the Late Cretaceous of Chhota Simla, central India. Palaeontology 54: 981-998.

WILSON J AND CARRANO M. 1999. Titanosaurs and the origin of 'wide-gauge' trackways: a biomechanical and systematic perspective on sauropod locomotion. Paleobiology 25: 252-267.

WILSON J AND CURRY ROGERS K. 2005. Introduction: monoliths of the Mesozoic. In Curry Rogers K, Wilson J (Eds), The Sauropods: Evolution and Palaeobiology. Berkeley: Univ of California Press: 1-15.

WILSON J, POL D, CARVALHO A AND ZAHER H. 2016. The skull of the titanosaur Tapuiasaurus macedoi (Dinosauria: Sauropoda), a basal titanosaur from the Lower Cretaceous of Brazil. Zool J Linn Soc 178: 611662.

WILSON J AND SERENO P. 1998. Early evolution and higher-level phylogeny of sauropod dinosaurs. Soc Verteb Paleont Mem 5: 1-68.

WILSON J AND UPCHURCH P. 2003. A revision of Titanosaurus Lydekker (Dinosauria - Sauropoda), the first dinosaur genus with a 'Gondwanan' distribution. J Syst Palaeont 1: 125-160.

ZAHER H, POL D, CARVALHO A, NASCIMENTO P, RICCOMINI C, LARSON P, JUÁREZ VALIERI R, 
PIRES-DOMINGUES R, DA SILVA N AND CAMPOS D. 2011. A complete skull of an Early Cretaceous sauropod and the evolution of advanced titanosaurians. PLoS ONE 6: e16663.

ZHANG Y. 1988. The Middle Jurassic Dinosaur Fauna from Dashanpu, Zigong, Sichuan, Vol. IV. Sauropod Dinosaurs (1), Shunosaurus. Chengdu: Sich Scient Tech Publ House.

\section{APPENDIX}

\section{SCORES FOR ADDITIONAL PHYLOGENETIC} CHARACTERS

The phylogenetic analysis in this paper is based on the dataset of González Riga et al. (2018), with the addition of three characters (C424-C426), the scores for which are as follows:

Omeisaurus: $424(0), 425(0), 426(0)$, Shunosaurus:424(0),425(0),426(0), Cedarosaurus: 424 (0), 425 (?), 426 (0), Apatosaurus: 424 (0), 425 (0), 426 (0), Diplodocus: 424 (0), 425 (0), 426 (0), Camarasaurus: 424 (0), 425 (0), 426 (0), Janenschia: 424 (0), 425 (0), 426 (0), Gobititan: 424 (1), 425 (1), 426 (?), Epachthosaurus: 424 (0), 425 (1), 426 (1), Mendozasaurus: 424 (1), 425 (1), 426 (1), Notocolossus: 424 (1), 425 (1), 426
(1), Opisthocoelicaudia: 424 (1), 425 (1), 426 (1), Alamosaurus: 424 (1), 425 (1), 426 (?).

\section{NOTE ADDED IN PROOF}

Since this paper went to press, another South American titanosaur that preserves appendicular skeletal remains has been formally described: Kaijutitan maui from the Upper Cretaceous (Coniacian) Sierra Barrosa Formation of Neuquén Province, northern Patagonia, Argentina (Filippi et al.2019). The type material of this large-bodied taxon includes multiple, mostly incomplete appendicular bones, in addition to cranial and postcranial axial remains. The preserved appendicular elements are as follows: incomplete scapula and coracoid, sternal plate, humerus, radius?, ulna, metacarpals II and III, incomplete ?ilium and femur, tibia, astragalus, and incomplete metatarsal II. Though the incompleteness of many of these bones renders comparisons difficult, most (e.g., the ulna and tibia) suggest a stout-limbed animal, comparable in this regard to Dreadnoughtus from Upper Cretaceous sediments in southern Patagonia. 